\title{
Endotoxin exposure and lung cancer risk: a systematic review and meta-analysis of the published literature on agriculture and cotton textile workers
}

\author{
Virissa Lenters • Ioannis Basinas • Laura Beane-Freeman • Paolo Boffetta • \\ Harvey Checkoway • David Coggon • Lützen Portengen • Malcolm Sim • \\ Inge M. Wouters $\cdot$ Dick Heederik $\cdot$ Roel Vermeulen
}

Received: 28 May 2009/Accepted: 20 November 2009/Published online: 12 December 2009

(C) The Author(s) 2009. This article is published with open access at Springerlink.com

\begin{abstract}
Objective To examine the association between exposure to endotoxins and lung cancer risk by conducting a systematic review and meta-analysis of epidemiologic studies of workers in the cotton textile and agricultural industries; industries known for high exposure levels of endotoxins. Methods Risk estimates were extracted from studies published before 2009 that met predefined quality criteria, including 8 cohort, 1 case-cohort, and 2 case-control studies of cotton textile industry workers, and 15 cohort and 2 case-control studies of agricultural workers. Summary risk estimates were calculated using random effects meta-analyses. Potential sources of heterogeneity were explored through subgroup analyses.

Results The summary risk of lung cancer was $0.72(95 \%$ CI, 0.57-0.90) for textile workers and 0.62 (0.52-0.75) for agricultural workers. The relative risk of lung cancer was below 1.0 for most subgroups defined according to sex, study design, outcome, smoking adjustment, and
\end{abstract}

V. Lenters - L. Portengen - I. M. Wouters - D. Heederik ·

R. Vermeulen $(\bowtie)$

Institute for Risk Assessment Sciences, Division Environmental Epidemiology, Utrecht University, P.O. Box 80178, 3508 TD

Utrecht, The Netherlands

e-mail: R.C.H.Vermeulen@uu.nl

I. Basinas

Department of Environmental and Occupational Medicine,

Institute of Public Health, Aarhus University, Aarhus, Denmark

L. Beane-Freeman

Occupational and Environmental Epidemiology Branch,

Division of Cancer Epidemiology and Genetics, National Cancer

Institute, National Institutes of Health, Bethesda, MD, USA

P. Boffetta

International Agency for Research on Cancer, Lyon, France geographic area. Two studies provided quantitative estimates of endotoxin exposure and both studies tended to support a dose-dependent protective effect of endotoxins on lung cancer risk.

Conclusion Despite several limitations, this meta-analysis based on high-quality studies adds weight to the hypothesis that occupational exposure to endotoxin in cotton textile production and agriculture is protective against lung cancer.

Keywords Endotoxins - Textile industry · Farmers · Lung cancer $\cdot$ Meta-analysis

\section{Introduction}

Reduced rates of lung cancer have been observed in several occupational groups who are exposed to high levels of organic dusts [1-3]. This reduced risk was initially

\section{H. Checkoway}

Department of Environmental and Occupational Health

Sciences, School of Public Health and Community Medicine,

University of Washington, Seattle, WA, USA

D. Coggon

MRC Epidemiology Resource Centre, University of

Southampton, Southampton, UK

M. Sim

Department of Epidemiology and Preventive Medicine, Monash University, Melbourne, VIC, Australia

D. Heederik $\cdot$ R. Vermeulen Julius Center for Health Sciences and Primary Care, University Medical Center Utrecht, Utrecht, The Netherlands 
attributed to inadequate adjustment for risk factors such as tobacco smoking [4, 5]. However, in 1973, Henderson and Enterline [1] proposed that endotoxins contaminating the dust inhaled by cotton textile workers might be responsible for the observed protective effect. Mastrangelo et al. [2] extended this proposition to dairy farmers as an explanation of their low mortality from lung cancer.

Endotoxin is a component of the outer membrane of Gramnegative bacteria and is released during replication and cell lysis. It is ubiquitous in indoor and outdoor environments. The highest endotoxin exposures have been measured in agricultural environments and certain occupational settings such as cotton textile mills [6]. Exposure primarily occurs through inhalation of airborne endotoxins present in organic dusts (also termed bioaerosols). Purified endotoxin is referred to as lipopolysaccharide (LPS), and the lipid-A portion, which is highly conserved across endotoxins originating from diverse bacterial species, is the biologically active component of endotoxins. Experimental studies in animals and a few trials in humans have shown that endotoxins can inhibit tumor initiation and growth and that endotoxins (or LPS) stimulate the production of endogenous antineoplastic mediators [7-9]. It has been suggested that immunomodulation is the primary anti-cancer mechanism, although evidence for mechanistic pathways is limited [10-12].

Previous meta-analyses found reduced lung cancer risks in studies of workers in the textile industry published before 1991 [13] and 2000 [3]. Several broad-based reviews have reported on cancer risks in farmers in the 1990s [14-16]. Unfortunately, few studies which investigated the association between lung cancer and employment in these industries included endotoxin or dust exposure measurements. This lack of exposure estimates hinders the ability to conclusively state that endotoxin is related to a decreased risk of lung cancer. We endeavored to examine more thoroughly the evidence on the relationship between occupational exposure to endotoxins and lung cancer risk, and to identify possible sources of heterogeneity in the relationship. We conducted a systematic review and selected high quality articles based on a priori set criteria for the meta-analysis. We focused on two industries which have been shown to involve high levels of endotoxin exposure-cotton textile manufacture and agriculture-for which several large scale studies had been published since the previously published meta-analyses.

\section{Methods}

\section{Search strategy}

We limited our review to studies of textile industry and agricultural workers due to the relatively low exposure levels in other occupational groups potentially exposed to endotoxins like waste-collection and treatment workers [17], veterinarians, and workers in paper factories [18], and due to the limited number of publications investigating risks of lung cancer in other occupational groups. We further narrowed our selection to cotton textile mill workers as there are few studies on lung cancer among workers in mills of other natural textile fibers (production of synthetic textiles entails negligible endotoxin exposures).

We searched the Medline and PubMed databases for all relevant articles published up to the end of 2008 using various combinations of the keywords endotoxin, farmers, agriculture, textile, cotton, lung and cancer. In addition, we scrutinized the reference lists of identified papers for additional relevant publications. If multiple articles were published on the same cohort, we included the most recent publication ( $n=5$ superseded publications [19-24]). We limited the retrieval to articles from English language peerreviewed journals.

\section{Criteria for inclusion and exclusion}

Two investigators (I.B., V.L.) extracted information on the type of exposure assessment or classification used in the analysis; the subjects' inclusion criteria; the comparison/control group; the statistical methods used; and the confounders considered in the analysis. We initially considered the quality components of the NewcastleOttawa Scale [25], a scale designed to assess non-randomized studies for meta-analyses. The scale evaluates selection of the cohort, exposure assessment, comparability of exposed and non-exposed cohorts, assessment of outcome, and adequacy of follow-up. We supplemented the quality assessment criteria based on the framework presented by Vlaanderen et al. [26], which specifically focuses on the quality of exposure assessment applied in human observational studies.

Proportionate mortality studies (PMR) were excluded ( $n=12$ [27-38]) as their results depend on the proportions of death from different causes [39]. Case-control studies that used cancer or respiratory disease patients as comparison groups were also excluded ( $n=10$ [40-49]) as such comparison is potentially biased [50]. Finally, studies that insufficiently described subject selection and statistical procedures were excluded ( $n=1[51])$.

\section{Data extraction}

The risk estimates derived from the model including the largest number of covariates and their associated $95 \%$ confidence intervals (CI) were extracted. Among the 
studies included in the meta-analysis, risk estimates were expressed as standardized mortality ratios (SMR), standardized incidence ratios (SIR), relative risks (RR), and hazard ratios (HR) in the cohort and case-cohort studies, and as odds ratios (OR) in the case-control studies. If a study reported multiple estimates for independent subpopulations, for instance according to job classification, duration of exposure categories, or gender, these were reported in "Appendix 1". If a cohort study did not report an overall risk estimate, estimates were combined into one risk estimate using the inverse of the variance as weight (Table 1). If subject groups overlapped within a study, the most inclusive estimate was used. Sex-specific estimates were also extracted. A $95 \%$ CI was calculated using Fisher's exact method for those studies that did not report a CI [52]. Standard errors (SE) were derived from 95\% CIs by taking the natural logs of the risk ratio and limits of the $\mathrm{CI}$, calculating the CI legs, and applying the z-distribution standard deviate to the averaged CI legs.

\section{Statistical analysis}

Statistical analyses were performed with the "metan" and "metabias" commands in STATA, version 10.1 (STATA Corporation, College Station, TX). The data entered into this statistical package were the natural log-transformed risk ratios and associated SEs. The coefficient of inconsistency $\left(I^{2}\right)$ was applied to assess heterogeneity between studies [53]. $I^{2}$ is an estimate of the percentage of total variation in study estimates due to heterogeneity rather than chance, and is considered substantial if it exceeds $50 \%$. We deemed the random effects assumptions to be most appropriate for this set of heterogeneous studies, and therefore present only these results. Random effects models [54] were applied to calculate the (reverse transformed) pooled risk ratios and associated $95 \% \mathrm{CIs}$, and $\mathrm{z}$ scores of all studies in each occupational group; textile and agricultural.

We performed subgroup analyses to assess whether any observed between-study heterogeneity was due to study characteristics or differences in quality. Heterogeneity between subgroups was tested using the PROC MIXED procedure with maximum likelihood estimation, SAS 9.1 (SAS Institute Inc., Cary, NC), and was considered significant if the $p$ value of the type $3 F$-test was below 0.1 . We refrained from assigning and weighting studies based on quality scores, as this can produce biased pooled estimates [55]. The subgroups defined a priori were, newer versus older studies, study design, mortality versus morbidity outcome, adjustment for smoking, geographic area, and sex. Too few studies stratified results by job title within the cotton industry or by farm type to perform subgroup analyses for these variables.

Publication bias was assessed by constructing funnel plots of the log risk ratio versus the SE of the log risk ratio [56], although we acknowledge the limitations of this method [57]. To supplement the funnel plot approach, the adjusted rank correlation method suggested by Begg and Mazumdar [58] and the regression asymmetry test proposed by Egger et al. [59] were applied.

\section{Results}

Characteristics of studies analyzed

Eight cohort [1, 60-66], 1 case-cohort [67], and 2 casecontrol [68, 69] studies in cotton textile industry workers, along with 15 cohort [2, 70-83] and 2 case-control [84, 85] studies in agricultural populations fulfilled the quality assessment criteria and were included in the meta-analysis. Tables 1 and 2 summarize characteristics of the studies included in the present meta-analysis; characteristics of all studies considered for inclusion, and application of the inclusion criteria are further elaborated in the "Appendices 1 and 2", respectively.

Both an SMR and SIR analysis were reported for the same cohort of Icelandic farmers [81, 86]; only the latter estimate, published more recently, was included in the meta-analysis. Two studies reported on the Agricultural Health Study in the same year [80, 87]. The SIR from Alavanja et al. [80], rather than the SMR from Blair et al. [87], was included as the study had a longer follow-up and is based on cancer incidence rather than cancer mortality. This study was designed to investigate the risks associated with pesticide exposure, but was nevertheless included as close to $90 \%$ of subjects were farmers. We further restricted our analysis to the SIR reported for private applicators, who were almost exclusively farmers.

The numbers of lung cancer cases captured by these studies were 1,217 and 6,216 within the 11 textile industry studies and 17 agricultural industry studies, respectively.

Quantitative data synthesis and heterogeneity

Tables 3 and 4 present the summary and subgroup risk estimates for cotton textile and agriculture workers, respectively. The summary risk $(95 \% \mathrm{CI})$ of lung cancer was $0.72(0.57-0.90)$ in the cotton textile industry and 0.62 $(0.52-0.75)$ in the agricultural industry. Both occupational 


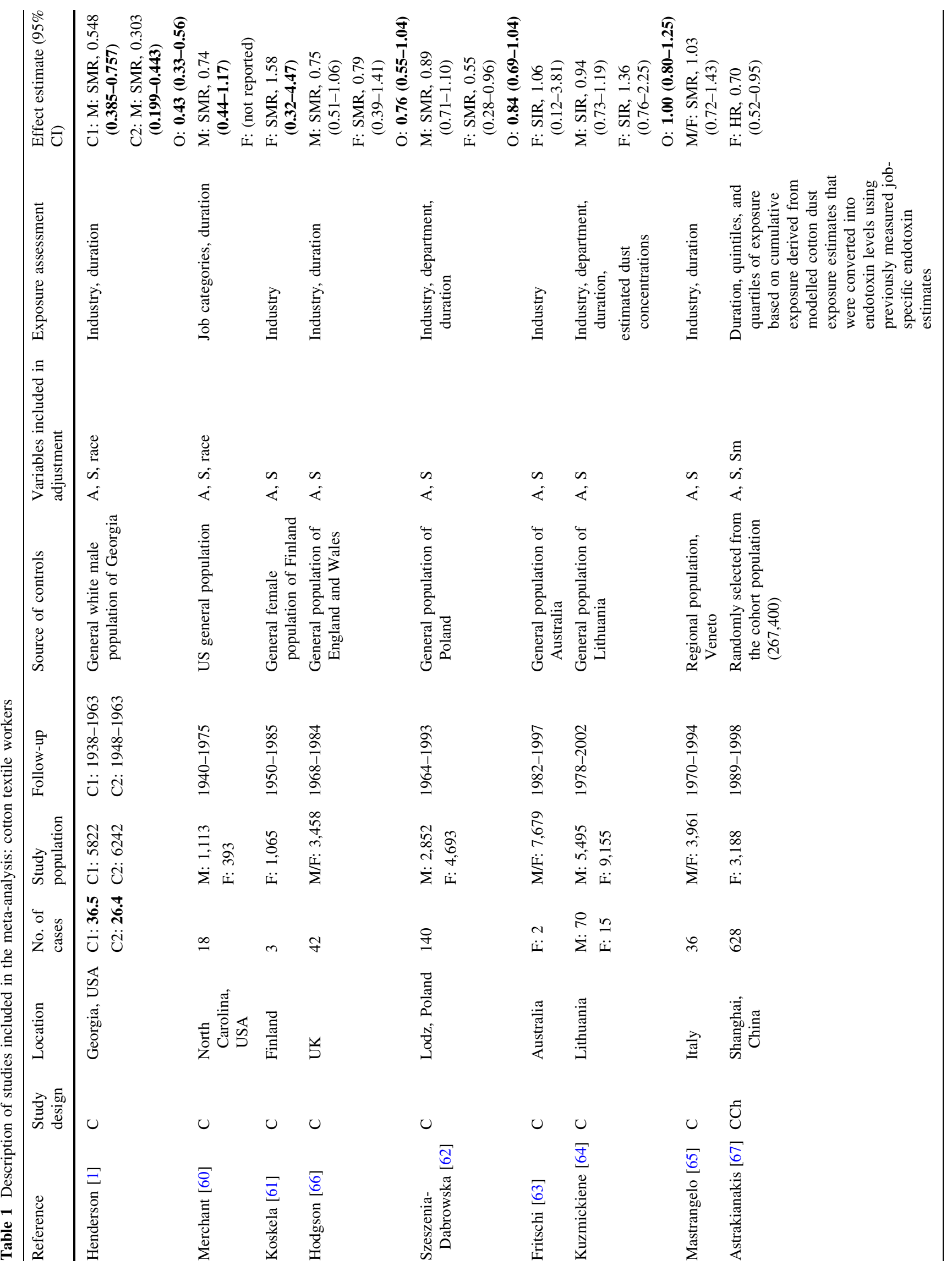




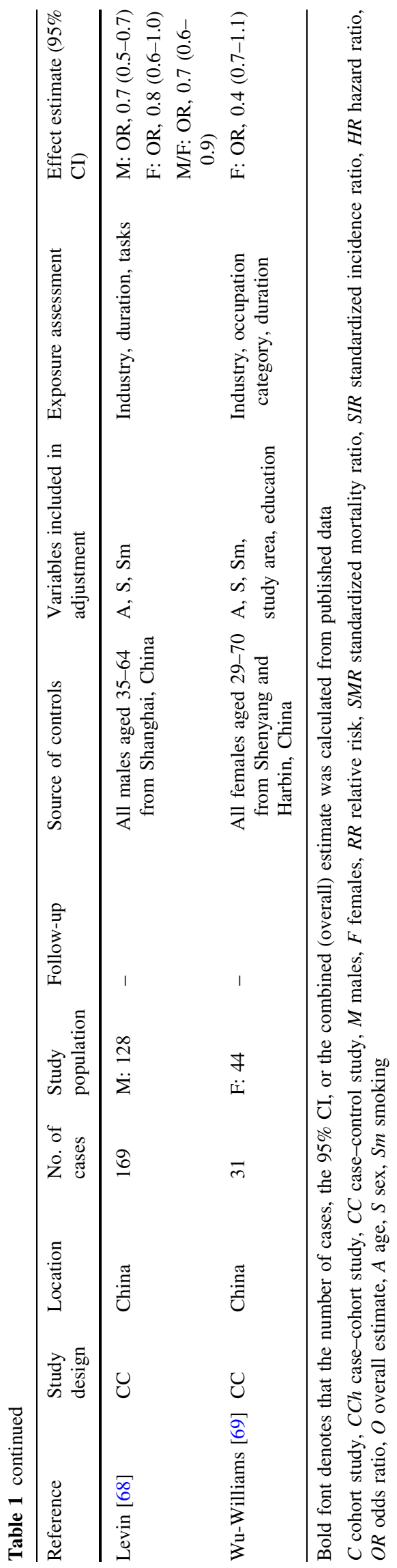

groups had reduced risks of lung cancer, as is presented graphically in Fig. 1.

The textile industry studies displayed considerable heterogeneity; the $I^{2}$ was greater than $69 \%$ in most subgroups (Table 3). The magnitude of the reduction in risk was greater for the studies from China and the USA than from Europe and greater than the one estimate from Australia (RR (95\% CI) of 0.58 (0.40-0.85), 0.54 (0.32-0.92), 0.91 (0.80-1.03), and $1.06(0.19-5.97)$, respectively). Textile industry studies that adjusted for smoking yielded a lower summary risk, $0.58(0.40-0.85)(n=3)$, than those that did not adjust for smoking, $0.79(0.61-1.03)(n=8)$, a difference that was of borderline statistical significance. The summary RR for cohort studies was 0.78 (0.62-0.98), and for case-control studies, 0.53 (0.31-0.92).

The risk estimates from agricultural studies exhibited even more heterogeneity than the textile industry studies, with an $I^{2}$ of greater than $82 \%$ for all subgroups with more than three studies (Table 4). Studies that adjusted for smoking $(n=3)$ had a summary RR of $1.19(0.94-1.50)$ versus $0.55(0.45-0.67)$ for the studies that did not. The two case-control studies yielded $1.32(1.00-1.74)$, and the cohort studies had a lower summary RR $(n=15)$ of 0.57 $(0.47-0.69)$. The meta-estimates of risk from the studies in Europe and the USA were similar, and significantly lower than the one estimate from China (0.60 (0.48-0.75), 0.59 (0.41-0.86), 1.60 (0.99-2.58), respectively).

In both textile industry and agricultural studies, metarisk estimates were lower in earlier published studies, and in studies reporting morbidity versus mortality outcomes, although these differences were not statistically significant. The sex-specific meta-risk estimates did not differ in the textile industry cohorts, but a non-significant lower metarisk estimate was found for female when compared with male agricultural workers.

\section{Publication bias}

The graphical funnel plots appeared symmetrical for studies from both occupational groups (Fig. 2). There was little evidence of publication bias among either textile industry or agricultural studies, according to Begg and Mazumdar's test and Egger's test $(p>0.20)$.

\section{Discussion}

This meta-analysis substantiates the available evidence of a reduced risk of developing lung cancer among people occupationally exposed to organic dusts commonly associated with high levels of endotoxin. The apparent protective effect of endotoxin exposure on lung cancer risk has 


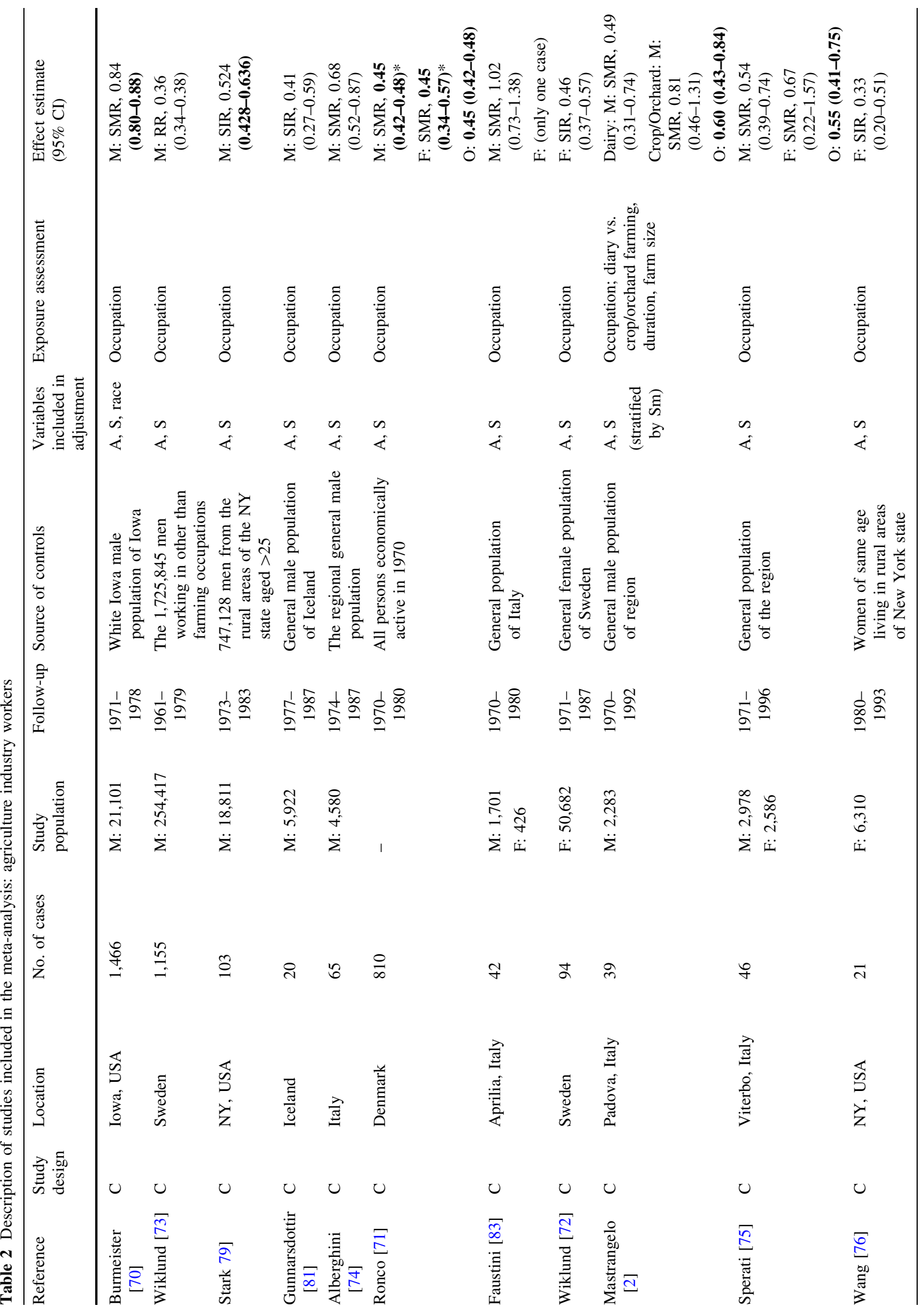




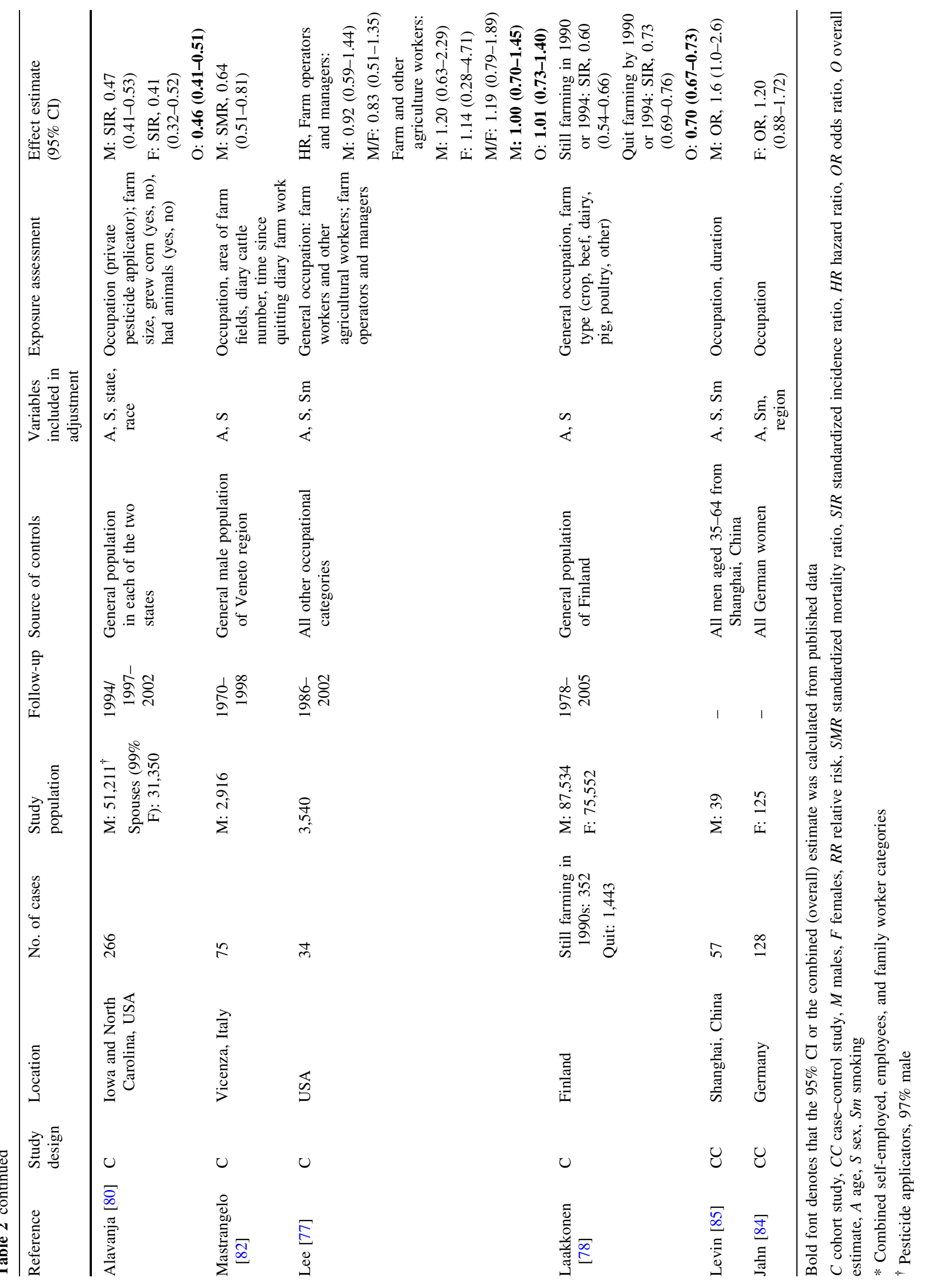


previously been postulated to result from healthy worker selection effect, inadequate adjustment for important confounders such as exposure to tobacco smoke, and/or inadequate comparison groups $[4,5]$. Exploring the influence of several variables via subgroup analysis revealed that results were overall robust, and consistently indicated a reduced risk in both cotton textile mill workers and farmers, occupations known to involve high endotoxin exposure [88, 89]. In addition, the current meta-analysis illuminates sources of heterogeneity in this relationship which would need to be clarified in future studies on this topic.

Mastrangelo et al. [3] pooled cancer risks associated with working in a cotton textile factory from eight studies published up to 1999 [1, 42, 60, 62, 66, 68], and calculated a reduced risk for lung cancer of $0.87,95 \%$ CI $0.81-0.93$. The CI is narrower than the one presented in this study, probably because Mastrangelo et al. employed a fixed effect model. Given the large heterogeneity in study results observed, a random effects model seemed more appropriate at least for our analyses. For comparison purposes, applying a fixed effects model resulted in the meta-risk estimate of $0.69,95 \%$ CI $0.63-0.75$ for textile industry studies. Su et al. [13] pooled 5 SMRs from four cohorts also included in the current meta-analysis $[1,60,61,66]$ and reported a meta-SMR (95\% CI) from presumably a fixed effect metaanalysis of $0.60(0.39-0.73)$ for male textile workers and $0.89(0.40-1.38)$ for female textile workers. In contrast with $\mathrm{Su}$ et al., we did not find an appreciable difference between female and male meta-risk estimates. This is possibly explained by our inclusion of the results from the large cohort of Shanghai female textile workers and several other recent studies.

A meta-analysis of cancers in farmers by Acquavella et al. [15] reported a summary lung cancer RR (95\% CI) of 0.65 (0.58-0.73) for 29 studies (including 11 PMR studies excluded from the current analysis) pooled in a random effects model. This is similar to the result of the current meta-analysis. Davis et al. [16] added observed and expected cases of lung cancer from 24 studies published prior to 1991 and reported a combined relative risk $(95 \%$ CI) of 0.66 (0.64-0.67) for farmers. We excluded some of the studies as they were PMRs, studies that employed other cancer patients as controls, or reports not published in peerreviewed journals. As such, our meta-analysis is based solely on studies that met predefined quality control criteria. The evidence from currently available studies is insufficient to draw a definite conclusion about a causal association between endotoxin exposure and lung cancer risk. Few of the studies assigned quantitative estimates of exposure to the subjects or grouped subjects based on estimated categories of exposure, hindering meaningful dose-response analyses in this meta-analysis. Notably, however, there was evidence of a dose-response relationship in the two studies that did derive estimates of exposure. The study on Shanghai textile workers modelled and assigned endotoxin exposure to cases and controls and found an inverse dose-response relationship between endotoxin levels and lung cancer [67]. In a cohort of Lithuanian textile workers, lung cancer risk decreased for both males and females with increasing quartiles of cotton textile dust cumulative exposure [64].

In the cotton textile industry, airborne concentrations of endotoxin are higher in the early stages of cotton processing - the opening and carding operations-compared with later processes such as spinning and weaving [90, 91]. Of the studies that met the inclusion criteria, only three stratified by job title [62, 65, 68]. In a cohort of Italian cotton mill workers, Mastrangelo et al. [65] reported the greatest reduction in lung cancer SMRs for those workers in carding jobs, which presumably had the highest endotoxin exposure levels, and for those with the longest duration of employment. In the studies that stratified by job task, those workers who did other tasks (such as administration, packaging or maintenance) had higher lung cancer risks than those with job tasks likely to involve higher endotoxin exposures, such as preparers, spinners, and weavers [60, 62, 68]. A study on cotton textile workers in Lithuania also found that longer duration of employment ( $>10$ years) and increasing exposure levels were associated with greater reductions in lung cancer risk in men, but these patterns were not observed in the female workers [64]. Most studies that investigated lung cancer patterns by duration of employment among both cotton textile and agricultural workers found deficits associated with increased years of employment [1, 64, 66, 69, 82], although several studies did not find this $[60,68]$. Even though no quantitative information is available in most evaluated studies, results based on proxies of exposure intensity and duration seem in general to corroborate a dose-dependent effect.

Heterogeneity of the observed protective effect among textile studies may also be explained by factors related to exposure intensity such as the origin of the cotton, which is known to influence bale moisture and thus endotoxin levels [92]. This might explain the observed differences in the protective effect between China and the US and Europe. Endotoxin concentrations, expressed as Endotoxin Units per cubic meter of air $\left(\mathrm{EU} / \mathrm{m}^{3}\right)$ or per milligram of dust (EU/mg), have been measured with the Limulus amebocyte lysate (LAL) assay, albeit with inter-laboratory variation of 
Table 3 Summary risks presented for meta-analyses of all studies and subgroups within the cotton textile industry

\begin{tabular}{|c|c|c|c|c|c|c|}
\hline & $\begin{array}{l}\text { No. of } \\
\text { studies }\end{array}$ & $\begin{array}{l}\text { Summary RR } \\
(95 \% \mathrm{CI})\end{array}$ & $Z(p \text { value })^{*}$ & $\begin{array}{l}\text { Heterogeneity } \\
I^{2}(p \text { value })^{\dagger}\end{array}$ & $\begin{array}{l}\text { Test of heterogeneity } \\
\text { between subgroups }\end{array}$ & References \\
\hline All studies & 11 & $0.72(0.57-0.90)$ & $2.91(0.004)$ & $82.5 \%(<0.001)$ & & {$[1,60-69]$} \\
\hline \multicolumn{7}{|l|}{ Published } \\
\hline Until 1990 & 5 & $0.66(0.49-0.87)$ & $2.88(0.004)$ & $69.4 \%(0.011)$ & \multirow[t]{2}{*}{0.516} & {$[1,60,61,66,68$} \\
\hline Post-1990 & 6 & $0.76(0.54-1.08)$ & $1.55(0.120)$ & $87.8 \%(<0.001)$ & & {$[62-65,69]$} \\
\hline \multicolumn{7}{|l|}{ By study design } \\
\hline Cohort* & 9 & $0.78(0.62-0.98)$ & $2.15(0.031)$ & $73.4 \%(<0.001)$ & \multirow[t]{2}{*}{0.152} & {$[1,60-67$} \\
\hline Case-control & 2 & $0.53(0.31-0.92)$ & $2.27(0.023)$ & $92.4 \%(<0.001)$ & & {$[68]$} \\
\hline \multicolumn{7}{|l|}{ By outcome } \\
\hline Mortality & 6 & $0.75(0.55-1.03)$ & $1.80(0.072)$ & $78.5 \%(<0.001)$ & \multirow[t]{2}{*}{0.587} & {$[1,60-62,65,66$} \\
\hline Morbidity & 5 & $0.68(0.47-0.98)$ & $2.05(0.041)$ & $87.9 \%(<0.001)$ & & {$[63,64,67-69]$} \\
\hline \multicolumn{7}{|c|}{ By smoking adjustment } \\
\hline No & 8 & $0.79(0.61-1.03)$ & $1.71(0.087)$ & $76.4 \%(<0.001)$ & \multirow[t]{2}{*}{0.179} & {$[1,60-66]$} \\
\hline Yes & 3 & $0.58(0.40-0.85)$ & $2.81(0.005)$ & $86.8 \%(0.391)$ & & [67-69] \\
\hline \multicolumn{7}{|c|}{ By geographic area } \\
\hline Australia & 1 & $1.06(0.19-5.97)$ & $0.07(0.948)$ & - & \multirow[t]{4}{*}{0.059} & [63] \\
\hline China & 3 & $0.58(0.40-0.85)$ & $2.81(0.005)$ & $86.8 \%(<0.001)$ & & {$[67-69$} \\
\hline Europe & 5 & $0.91(0.80-1.03)$ & $1.53(0.126)$ & $0.0 \%(0.460)$ & & {$[61,62,64-66]$} \\
\hline USA & 2 & $0.54(0.32-0.92)$ & $2.28(0.023)$ & $73.3 \%(0.053)$ & & {$[1,60]$} \\
\hline \multicolumn{7}{|l|}{$\operatorname{Sex} \|$} \\
\hline Male & 6 & $0.72(0.57-0.91)$ & $2.79(0.005)$ & $78.1 \%(<0.001)$ & \multirow[t]{2}{*}{0.523} & {$[1,60,62,64,66,68$} \\
\hline Female & 8 & $0.73(0.52-1.03)$ & $1.81(0.071)$ & $76.7 \%(<0.001)$ & & {$[61,62,64,66-69]$} \\
\hline
\end{tabular}

* Significance test of pooled effect estimate $=1$

${ }^{\dagger}$ Heterogeneity evaluated by $I^{2}$ and the $p$ value of chi-squared test for heterogeneity

* Including one case-cohort study [67]

$\S p$ value, considered significant if $<0.1$

$\|$ Sex-specific estimates, if provided, were combined in this analysis

up to one order of magnitude. Endotoxin levels generally range from 10 to $10,000 \mathrm{EU} / \mathrm{m}^{3}$ in the textile industry. As a precursory step in the exposure modeling for the Shanghai cohort, Astrakianakis et al. [88] combined data from five surveys, and showed that GM endotoxin levels ranged from approximately $60 \mathrm{EU} / \mathrm{m}^{3}$ near the spinning process to $3,600 \mathrm{EU} / \mathrm{m}^{3}$ near the carding process. Endotoxin levels generally decrease during the processing steps of opening, carding, drawing, combing, spinning, and weaving, as impurities are removed to produce a clean product. Median endotoxin concentrations in three Shanghai textile mills were $1,281 \mathrm{EU} / \mathrm{m}^{3}$ and $2,227 \mathrm{EU} / \mathrm{m}^{3}$ in samples collected from 14 areas and 41 personal samplers, respectively [93]. Other studies have reported geometric mean endotoxin values of 131 to $1,637 \mathrm{EU} / \mathrm{m}^{3}$ in four mills in Quebec, Canada [94]; a median level of $450 \mathrm{EU} / \mathrm{m}^{3}$ in a German cotton mill [95]; and a mean that ranged from 111.1 to $156.7 \mathrm{ng} / \mathrm{m}^{3}$ over 3 years in a cotton textile plant in Taiwan [96]. A study with 572 personal dust samples from workers in three Turkish cotton mills observed median levels of $2,135 \mathrm{EU} / \mathrm{m}^{3}$ for the open and card attendants, $5,857 \mathrm{EU} / \mathrm{m}^{3}$ for the waste room operatives, and much lower levels of $26-407 \mathrm{EU} / \mathrm{m}^{3}$ for the other occupational groups [97]. Comparisons of exposure levels between these studies should be made with caution as high inter-laboratory variation is known to exist. However, generally they are supportive of higher endotoxin exposure levels in the early stages of cotton processing.

An argument supporting a role for endotoxin in decreasing lung cancer risk is that lung cancer deficits have not been consistently observed in other (non-cotton) types of mills, in which exposure to endotoxin is lower. In the large cohort of Shanghai textile workers, lung cancer mortality was lowest in workers from the cotton textile spinning, weaving and knitting sector, versus the wool, silk, synthetic, mixed fiber textile sectors [21]. One study investigating lung cancer in a synthetic fiber mill found that lung cancer mortality was increased in workers exposed to 
Table 4 Summary risks presented for meta-analyses of all studies and subgroups within the agricultural industry

\begin{tabular}{|c|c|c|c|c|c|c|}
\hline & $\begin{array}{l}\text { No. of } \\
\text { studies }\end{array}$ & $\begin{array}{l}\text { Summary RR } \\
(95 \% \mathrm{CI})\end{array}$ & $Z(p \text { value })^{*}$ & $\begin{array}{l}\text { Heterogeneity } \\
I^{2}(p \text { value })^{\dagger}\end{array}$ & $\begin{array}{l}\text { Test of heterogeneity } \\
\text { between subgroups }\end{array}$ & References \\
\hline All studies & 17 & $0.62(0.52-0.75)$ & $4.97(<0.001)$ & $97.9 \%(<0.001)$ & & {$[2,70-85]$} \\
\hline \multicolumn{7}{|l|}{ Published } \\
\hline Until 1995 & 9 & $0.61(0.45-0.84)$ & $3.09(0.002)$ & $98.7 \%(<0.001)$ & \multirow[t]{2}{*}{0.473} & {$[70-74,79,81,83,85]$} \\
\hline Post-1995 & 8 & $0.64(0.52-0.80)$ & $4.00(<0.001)$ & $97.1 \%(<0.001)$ & & {$[2,75-78,80,82,84]$} \\
\hline \multicolumn{7}{|l|}{ By study design } \\
\hline Cohort & 15 & $0.57(0.47-0.69)$ & $5.62(<0.001)$ & $98.0 \%(<0.001)$ & \multirow[t]{2}{*}{0.005} & {$[2,73-78,80-83]$} \\
\hline Case-control & 2 & $1.32(1.00-1.74)$ & $1.98(0.048)$ & $0.0 \%(0.334)$ & & {$[84,85]$} \\
\hline \multicolumn{7}{|l|}{ By outcome } \\
\hline Mortality & 8 & $0.69(0.52-0.92)$ & $2.53(0.011)$ & $97.2 \%(<0.001)$ & \multirow[t]{2}{*}{0.108} & {$[2,20,74,75,77,80-83]$} \\
\hline Morbidity & 9 & $0.57(0.43-0.76)$ & $3.90(<0.001)$ & $98.0 \%(<0.001)$ & & {$[72,73,76,78,81,84,85]$} \\
\hline \multicolumn{7}{|c|}{ By smoking adjustment } \\
\hline No & 14 & $0.55(0.45-0.67)$ & $5.82(<0.001)$ & $98.2 \%(<0.001)$ & \multirow[t]{2}{*}{0.002} & {$[2,70-76,78-83]$} \\
\hline Yes & 3 & $1.19(0.94-1.50)$ & $1.47(0.142)$ & $17.0 \%(<0.001)$ & & {$[77,84,85]$} \\
\hline \multicolumn{7}{|c|}{ By geographic area } \\
\hline China & 1 & $1.60(0.99-2.58)$ & $1.93(0.054)$ & - & \multirow[t]{3}{*}{0.069} & {$[85]$} \\
\hline Europe & 11 & $0.60(0.48-0.75)$ & $4.48(<0.001)$ & $97.6 \%(<0.001)$ & & {$[2,20,73-75,78,81-84]$} \\
\hline USA & 5 & $0.59(0.41-0.86)$ & $2.79(0.005)$ & $96.8 \%(<0.001)$ & & {$[76,77,80]$} \\
\hline \multicolumn{7}{|l|}{$\operatorname{Sex}^{\|}$} \\
\hline Male & 13 & $0.63(0.49-0.81)$ & $3.66(<0.001)$ & $98.1 \%(<0.001)$ & \multirow[t]{2}{*}{0.366} & {$[2,70,71,73-75,77,79,81-83,85]$} \\
\hline Female & 7 & $0.54(0.39-0.75)$ & $3.61(<0.001)$ & $82.7 \%(<0.001)$ & & {$[71,72,75-78,80,84]$} \\
\hline
\end{tabular}

* Significance test of pooled effect estimate $=1$

${ }^{\dagger}$ Heterogeneity evaluated by $I^{2}$ and the $p$ value of chi-squared test for heterogeneity

$\S^{\S} p$ value, considered significant if $<0.1$

\| Sex-specific estimates, if provided, were combined in this analysis

\section{(A)}

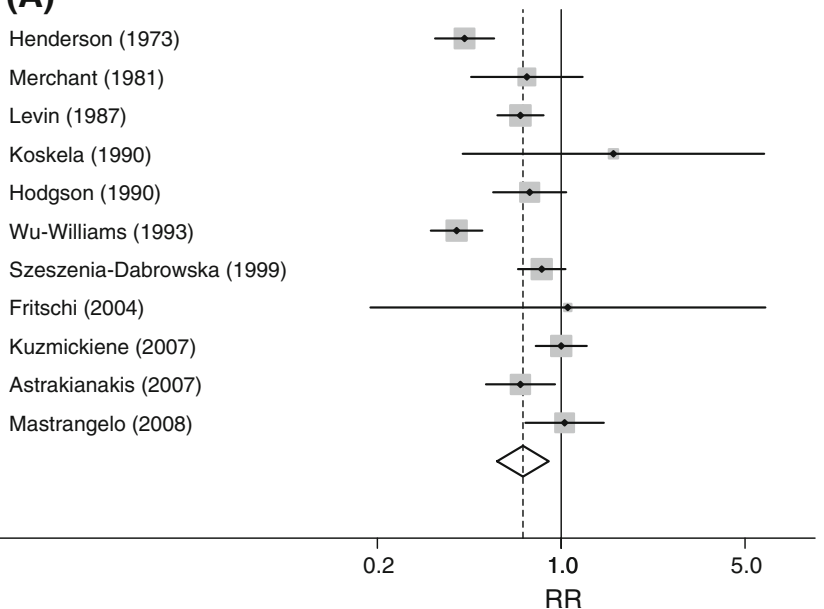

Fig. 1 Forest plots for study-specific and summary risk ratios with 95\% CIs for lung cancer risk associated with working in a the cotton textile industry and $\mathbf{b}$ agriculture. Studies were pooled with the random effects method and ordered by publication year. Squares
(B)

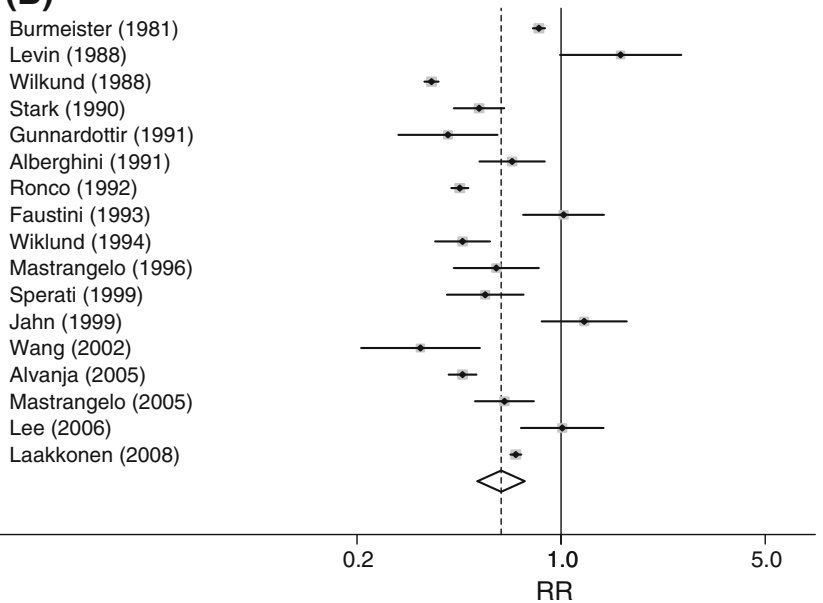

represent study-specific risk estimates (size of the square reflects the study-specific statistical weight); horizontal lines, the 95\% CIs; diamond, the summary risk estimate and its corresponding 95\% CI 

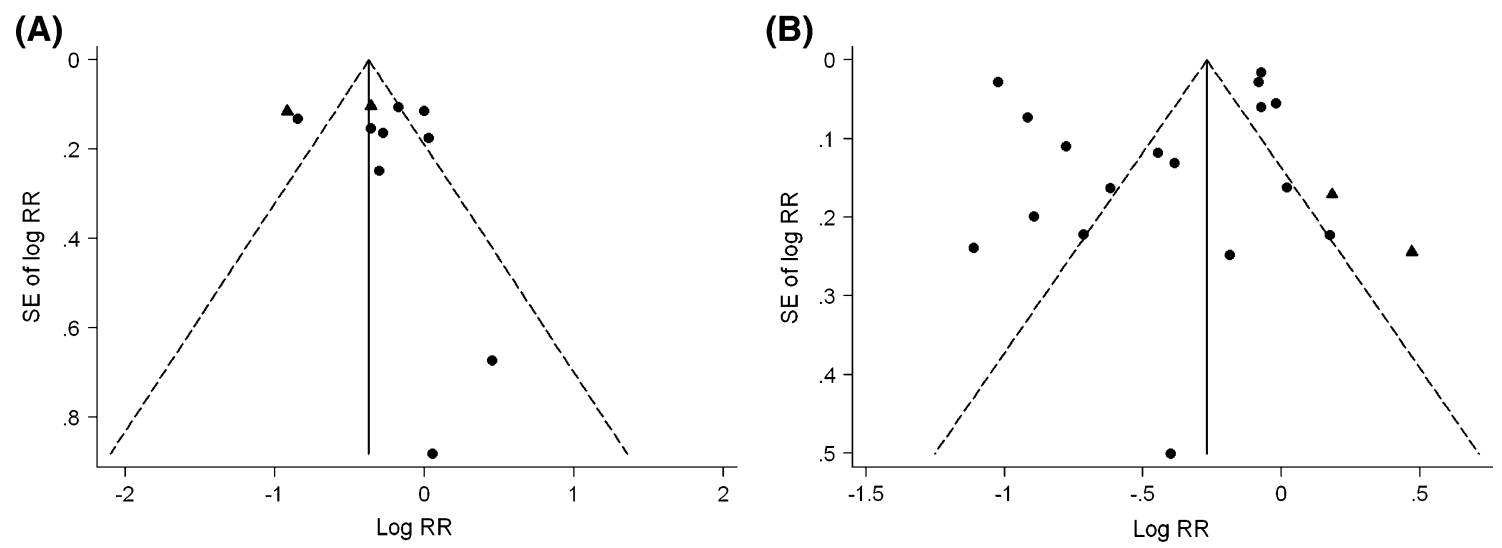

Fig. 2 Funnel plots of lung cancer risk ratios associated with working in a the cotton textile industry and $\mathbf{b}$ agriculture. Circles represent cohort studies; triangles represent case-control studies

increasing levels of dust [98]. Endotoxin levels are minimal in synthetic textile dusts, although levels slightly elevated compared to background levels $\left(<5 \mathrm{EU} / \mathrm{m}^{3}\right)$ have been documented in some mills due to contamination of humidification and lubricant mist systems [99]. Considering that covariate risk factors are unlikely to differ substantially between synthetic and cotton mills, the finding that lung cancer rates are lower in cotton versus synthetic mill workers is compelling evidence for a protective effect of endotoxin; however, these findings should be confirmed with further research.

It is possible that earlier cohorts exhibited greater deficits in lung cancer than more recent cohorts due to higher past exposures. While endotoxin and dust levels are only moderately correlated in cotton mills $(r=0.49, p<0.01)$ [90], measures to control workers' exposure to dust, such as improved ventilation and automation of processing, are likely to have resulted in lower cumulative dust and endotoxin exposures in more recent cohorts.

Determinants of endotoxin levels, such as process, sources, ventilation, and moisture, likely vary more between different agricultural settings than between cotton mills. Using a standardized protocol, Spaan et al. [89] reported a geometric mean (range) of 2,700 (96$41,200) \mathrm{EU} / \mathrm{m}^{3}$ for grain and legume primary production $(n=15)$, and $1,190(73-19,500) \mathrm{EU} / \mathrm{m}^{3}$ at primary production animal farms $(n=377)$. High endotoxin levels have been measured during machine harvesting of certain crops. However, cumulative annual endotoxin levels are likely to be higher with livestock than crop farming due to the seasonal nature of the latter. Two agriculture studies from Italy and Finland included in the present metaanalysis, that stratified by production type, found that dairy farmers had lower risks of lung cancer than crop farmers, as did the Finnish male farmers with poultry and pigs
$[2,78]$. Furthermore, farmers who switched from dairy to crop farming increased their lung cancer risk [78]. Although there are indications among both the textile workers and farmers of a possible dose-response relation between endotoxin exposure and reduced lung cancer risk, this evidence is still rather weak.

Smoking is a major risk factor for lung cancer. Pooling risk estimates based on whether they were adjusted for smoking yielded different results for the textile industry and agricultural studies; the adjusted meta-RR was lower for textile industry studies, whereas the opposite pattern was observed in the agricultural studies, although this difference was non-significant in the textile industry and for each industry, there were only three studies which adjusted for smoking. Two of the three studies that adjusted for smoking in both industries were case-control studies, and the differences in smoking adjusted and unadjusted meta-risk estimates paralleled the differences between cohort and case-control studies. It is thus not possible to state whether factors related to the study design or the adjustment for smoking most influenced the overall risks. It is known that in US populations, farmers have lower rates of smoking than the general population [80]. Assuming this pattern holds in populations outside the US, unadjusted risk estimates with general population controls would overestimate any protective effect of endotoxin exposure. However, there is some evidence from studies that present both unadjusted and adjusted risk estimates that upon adjustment for smoking, the protective effect associated with working as a farmer did not disappear $[82,84,85]$.

A limitation of this meta-analysis is the fact that most of the cohort studies are based on administrative data, such as registries, and thus often lack information on risk factors and estimates of endotoxin exposure, and as such working in the cotton textile or agricultural industries was used as 
proxies of exposure. Studies may suffer from residual confounding from factors such as lifestyle (e.g., diet, physical activity) and/or other occupational exposures; however, some studies have shown that adjustment for risk factors such as smoking does not substantially change effect estimates [100]. Conversely, non-differential exposure classification may have attenuated the effect estimates. The studies are highly heterogeneous, and populations differ in baseline risk, lifestyle factors and contrast in exposure. The validity of combining and comparing risk estimates from observational studies to obtain a more precise meta-risk estimate is disputed [101], although it should be noted that synthesizing evidence from observational studies is also an issue in non-meta-analytic reviews. A counter argument is that heterogeneity can be used to attempt to discern which factors influence risk, and that consistency from findings from heterogeneous studies can justify the generalizability of meta-analysis results $[102$, 103]. We did not identify any obvious sources of heterogeneity, or find convincing evidence that one study characteristic variable contributed more to heterogeneity of the meta-risk estimates than the others as there was clustering of the variables we examined. The subgroup meta-analyses demonstrated that the protective relation of working in industries with high endotoxin levels on lung cancer is robust upon consideration of important study characteristics.

Endotoxin exposure is possibly beneficial with respect to reducing lung cancer risk. However, it should be noted that studies indicate that acute exposure to cotton dust can cause chest tightness, organic dust toxic syndrome and byssinosis, and long-term exposure is associated with accelerated decline in lung function and chronic respiratory disease [104-106]. The potential protective effect of endotoxin is relevant in understanding the etiology of lung cancer, and perhaps with respect to developing anticarcinogenic therapeutics [107]. The lipid-A portion of endotoxin has been found to suppress tumor growth in animal models [10]. Explanations and evidence for plausible mechanistic pathways is limited. It seems that removing exposure-when farmers quit farming, or switch to a farming type with purportedly lower endotoxin exposures-causes deficits in lung cancer risk to disappear over time [78, 82]. It is unclear whether current exposure is protective, which intensity of exposure is relevant, and whether the protective effect diminishes with time elapsed since last exposure to endotoxins.

This meta-analysis of studies of two dissimilar occupational groups, agricultural and textile workers, despite several limitations, adds weight to previous evidence that exposure to endotoxin-contaminated organic dusts may lead to a reduced risk of developing lung cancer. Future research should investigate the dose-response relationship between endotoxin exposure and risk of lung cancer and focus on possible sources of heterogeneity in this relation. Quantifying exposures to organic dusts, endotoxin, and concurrent exposure to other biologically active agents may help solve the mechanistic pathways of the observed protective effect.

Acknowledgments Acknowledgment of financial support Not applicable.

Competing interests None.

Open Access This article is distributed under the terms of the Creative Commons Attribution Noncommercial License which permits any noncommercial use, distribution, and reproduction in any medium, provided the original author(s) and source are credited.

\section{Appendix 1}

See Table 5 . 


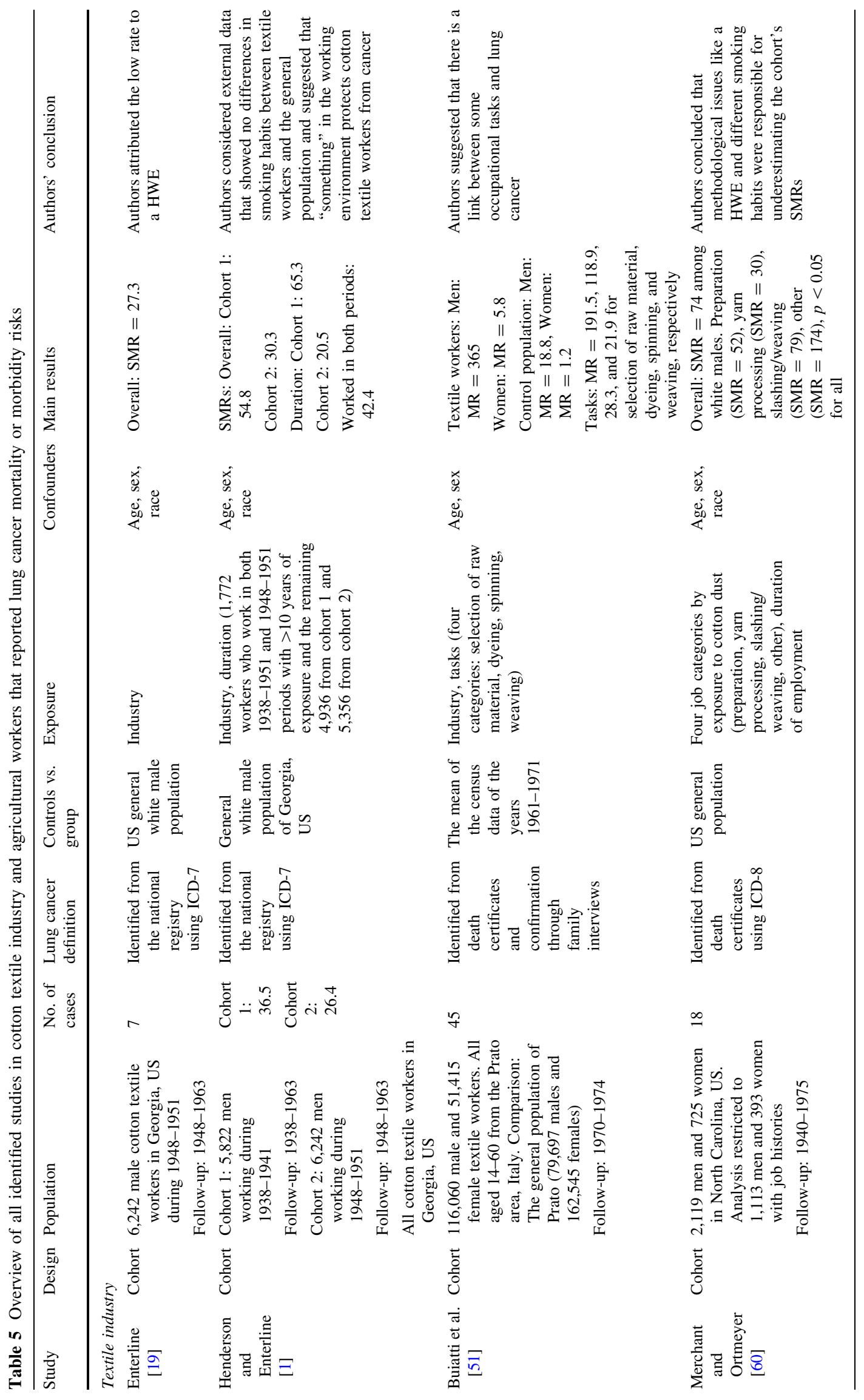




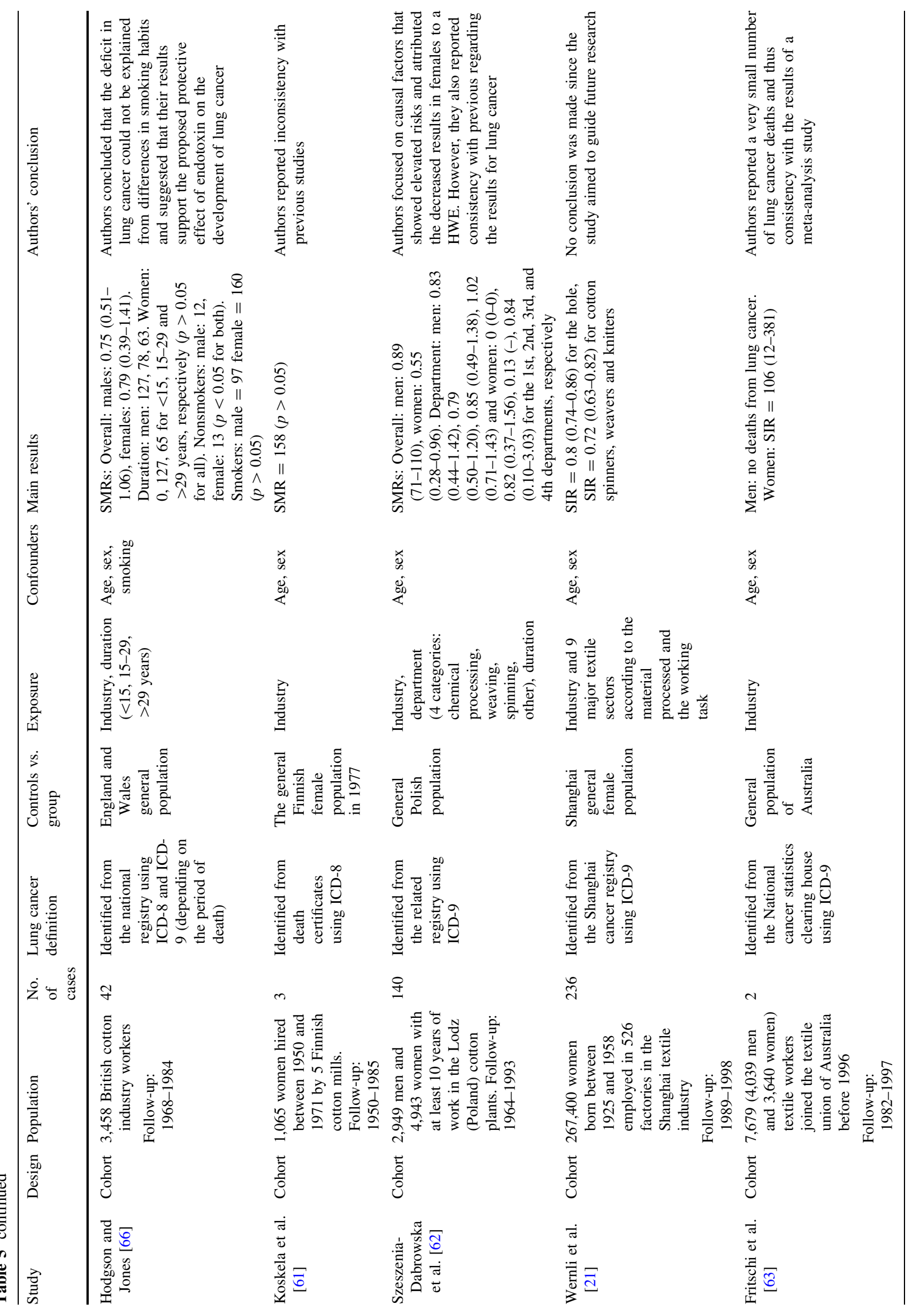




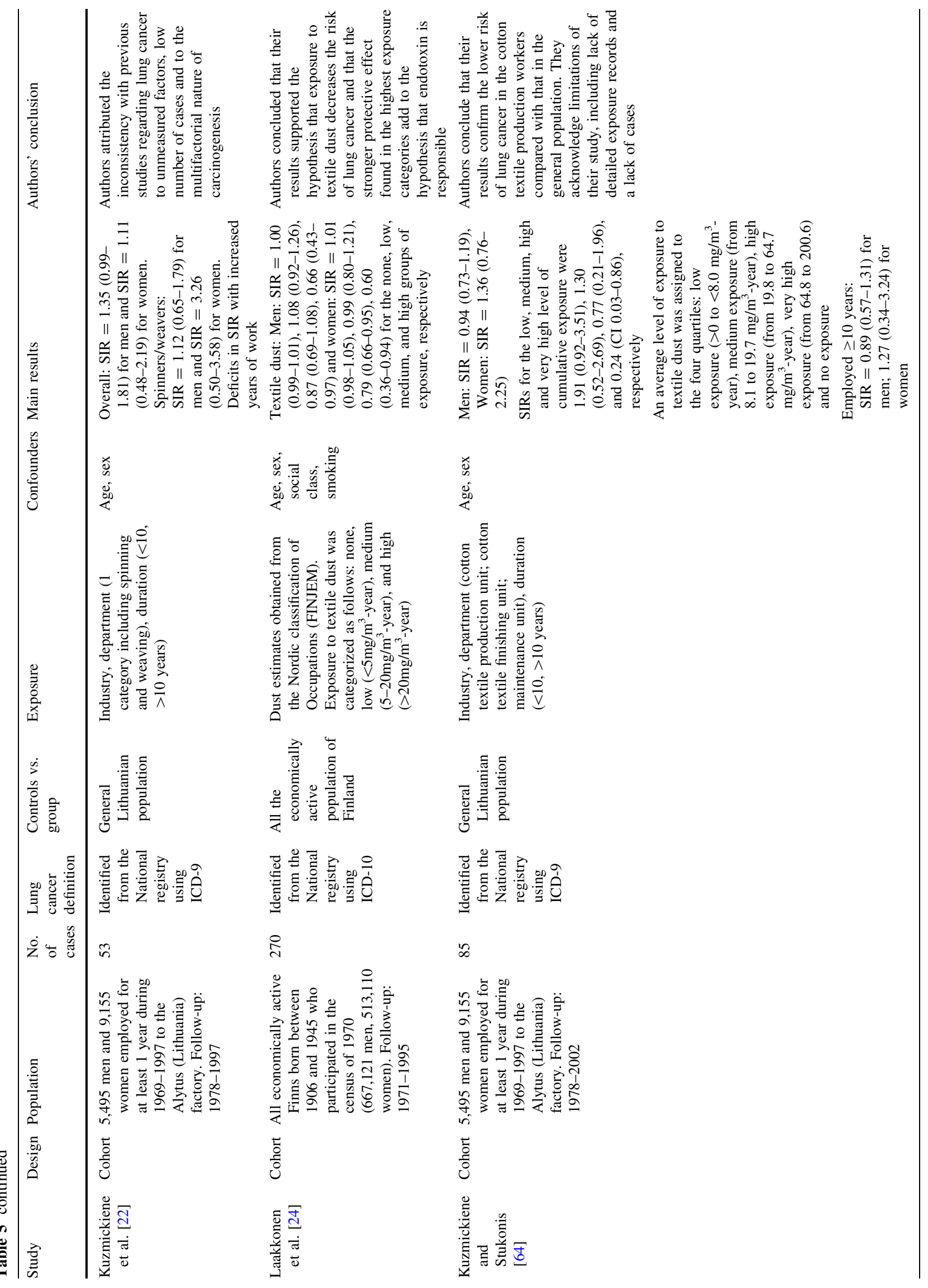




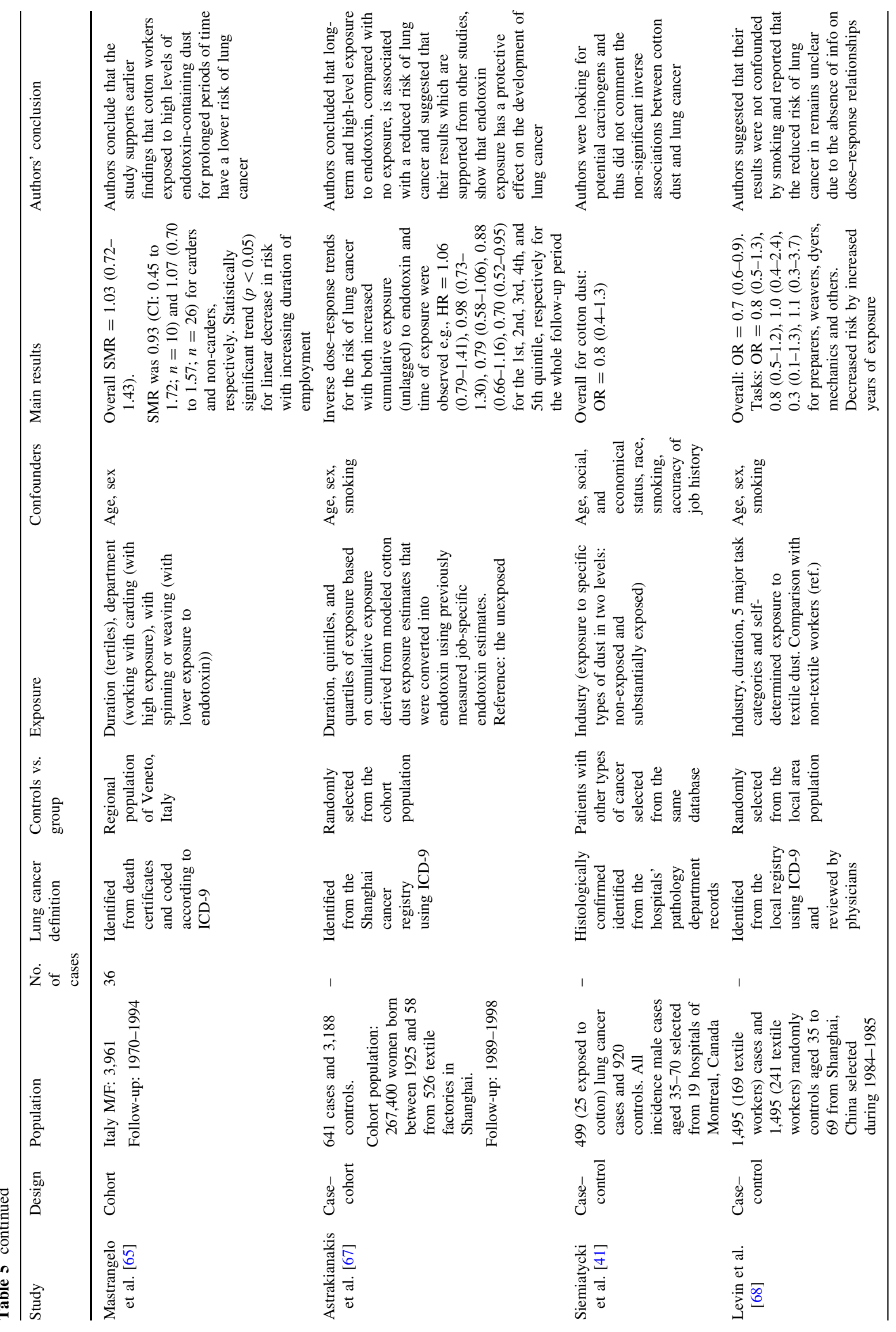




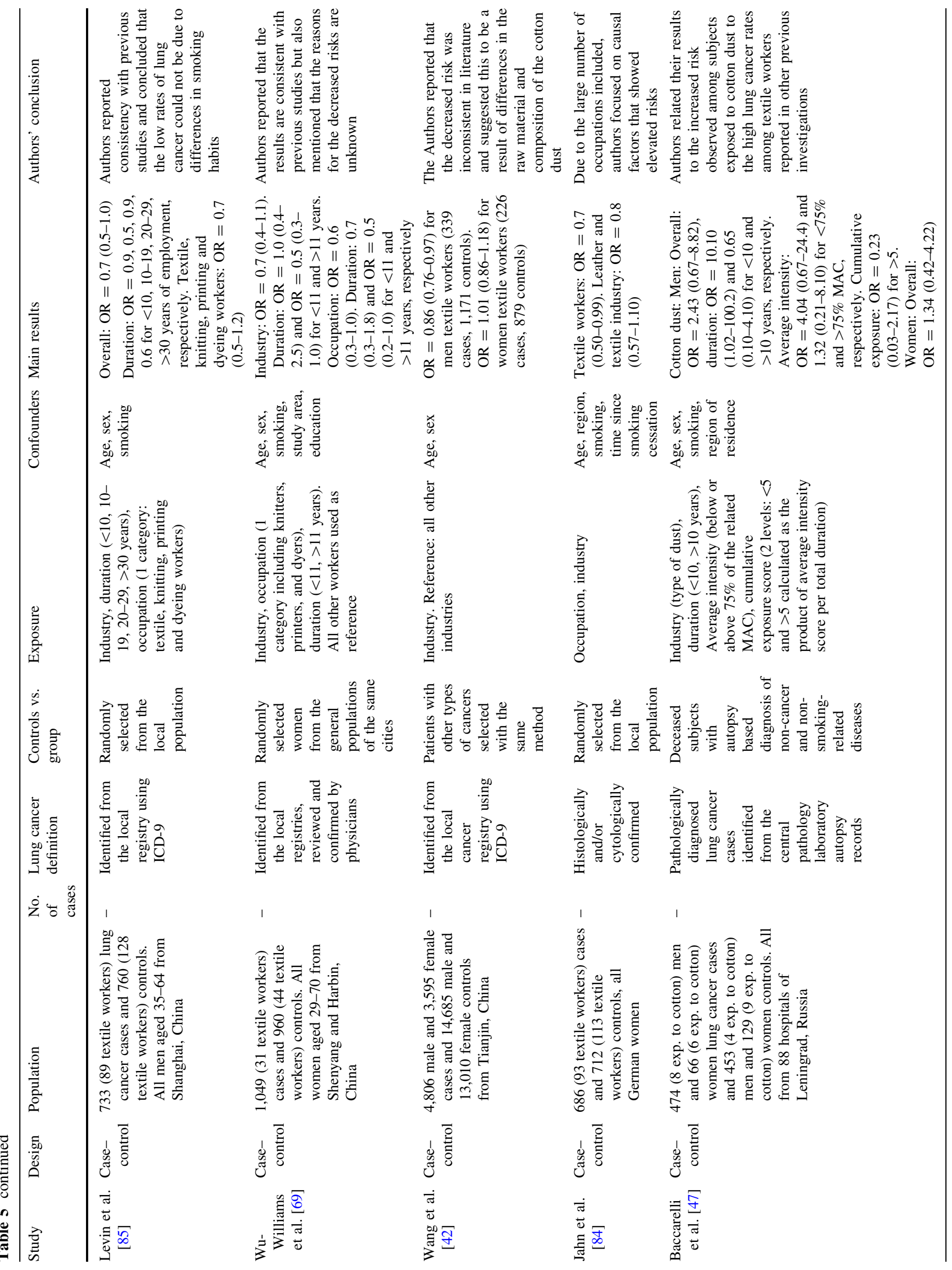




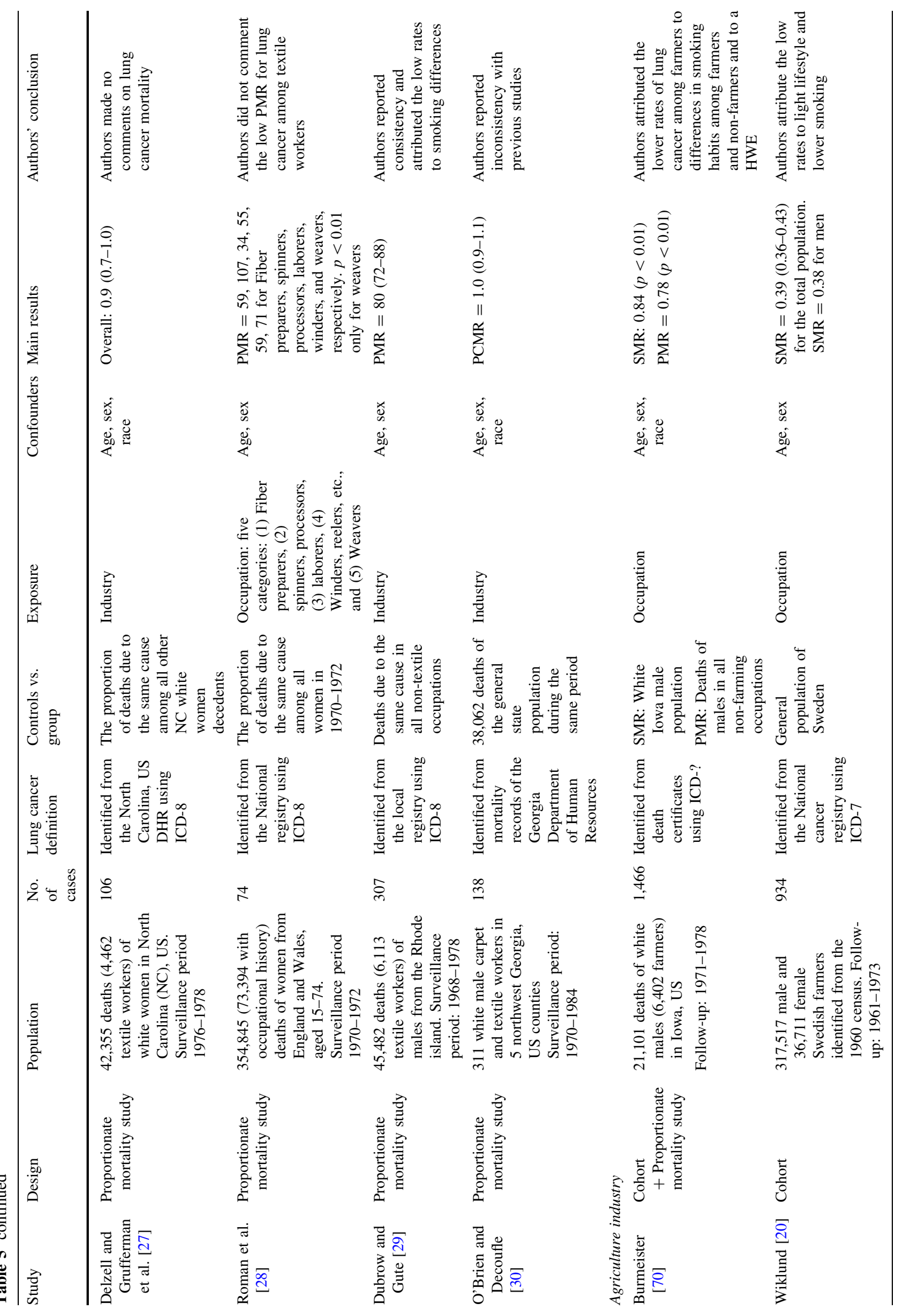




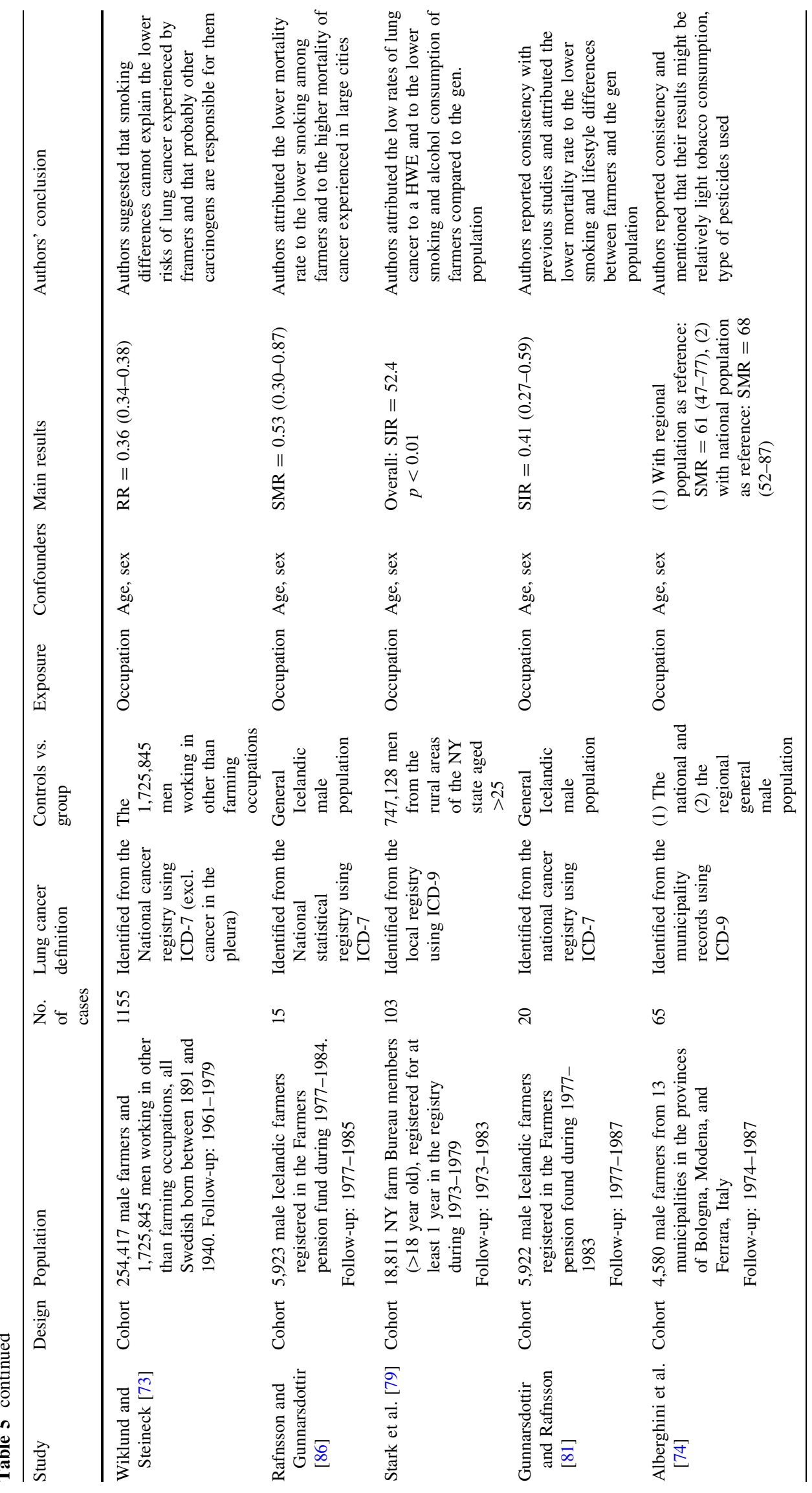




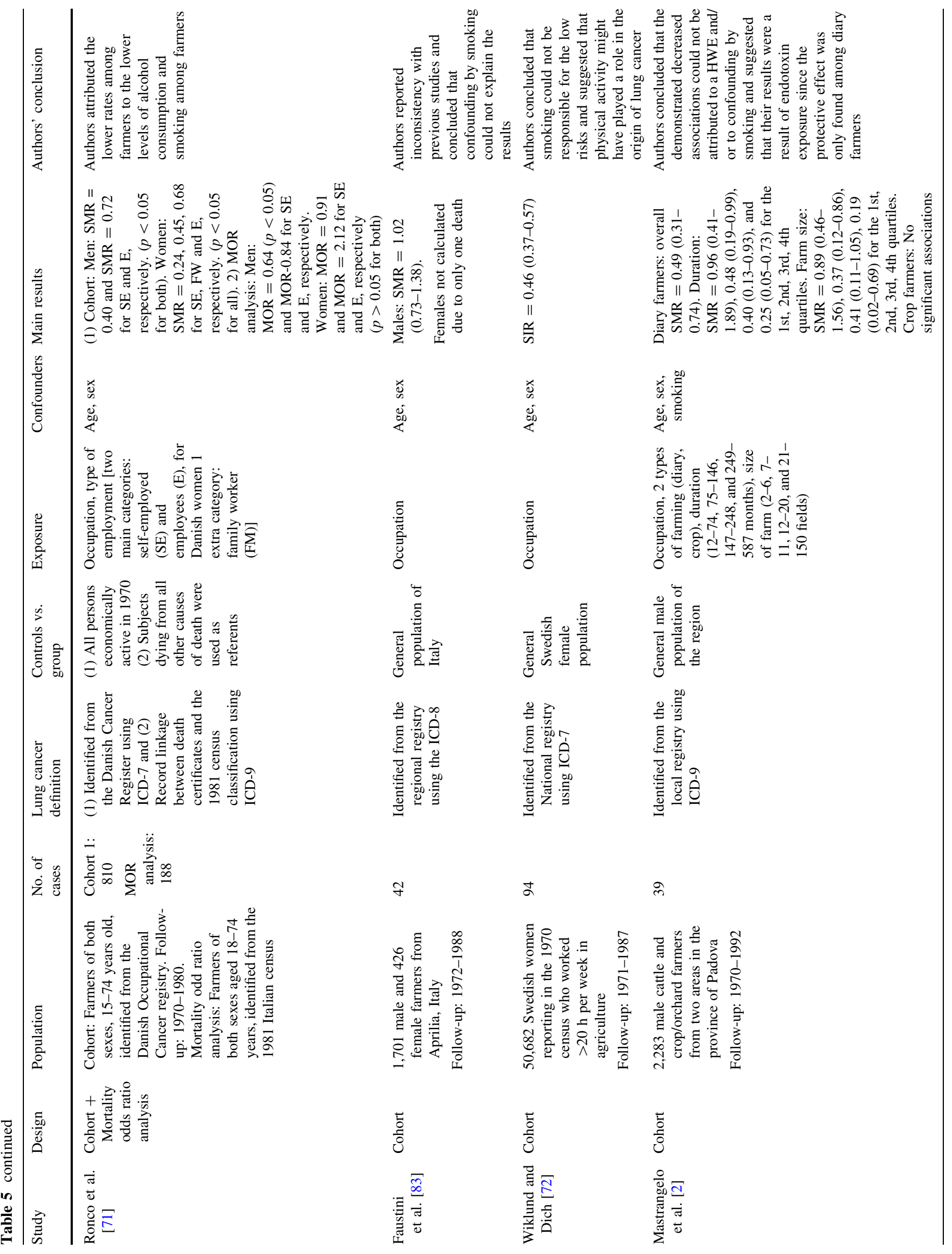




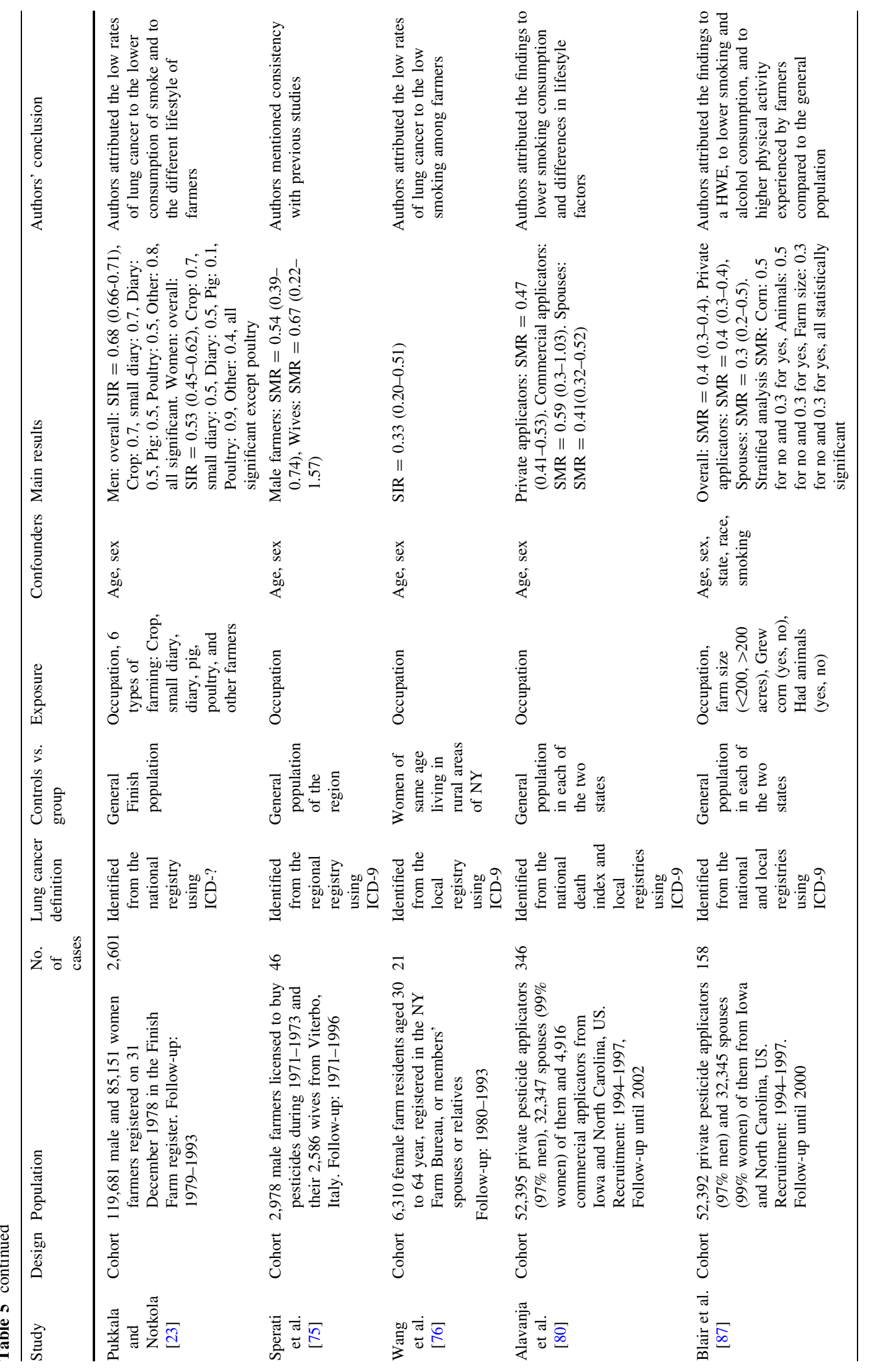




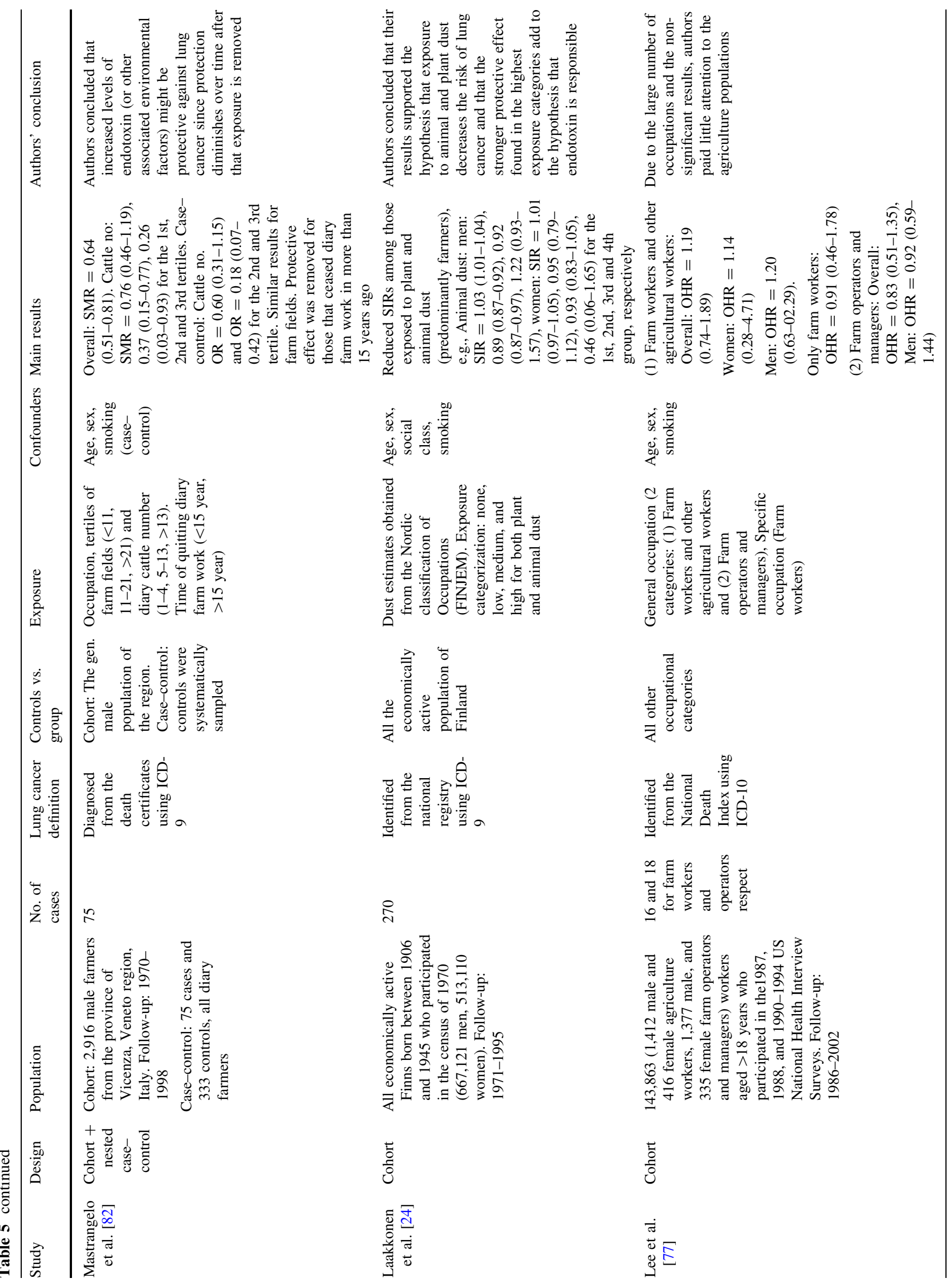




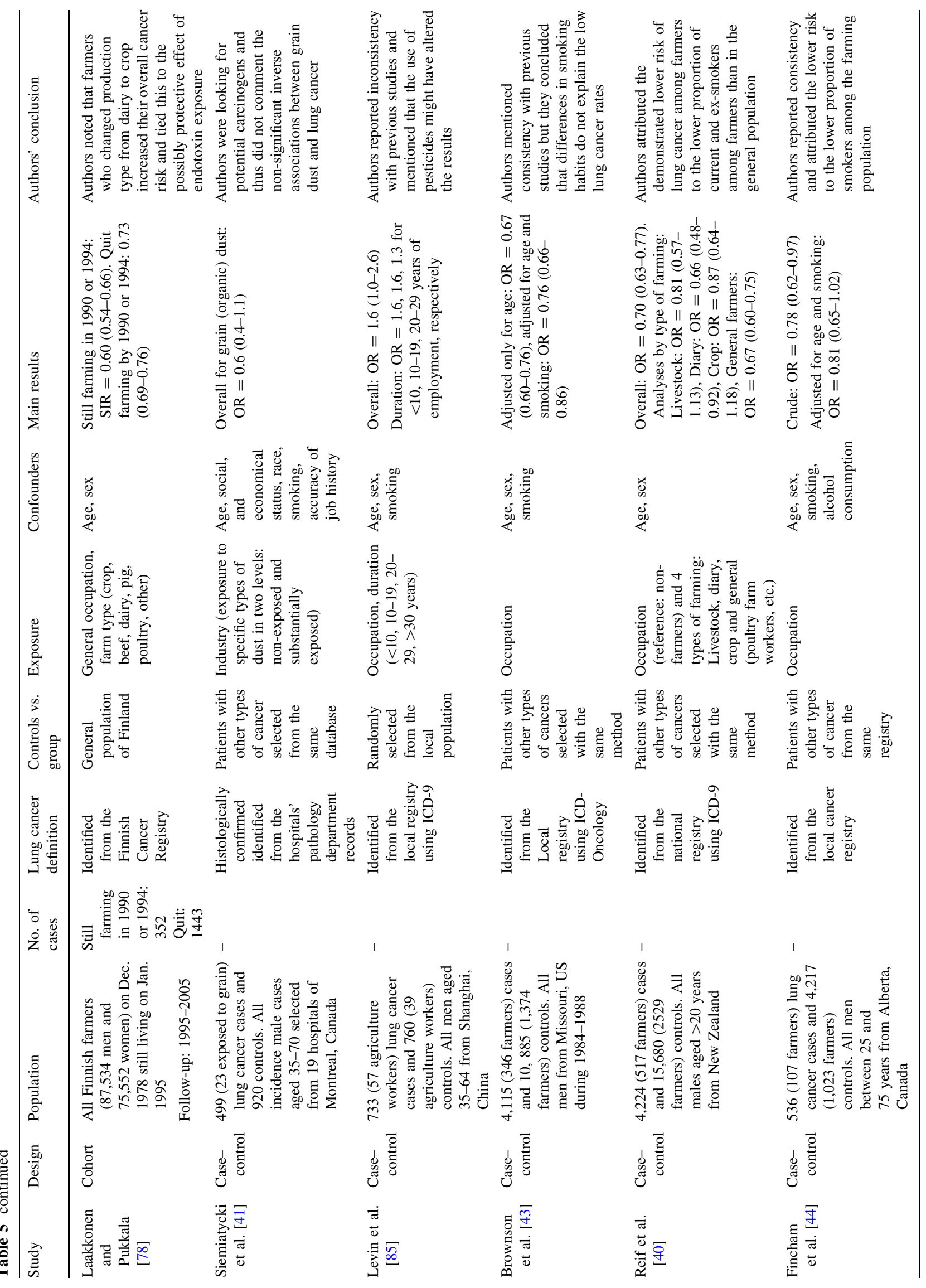




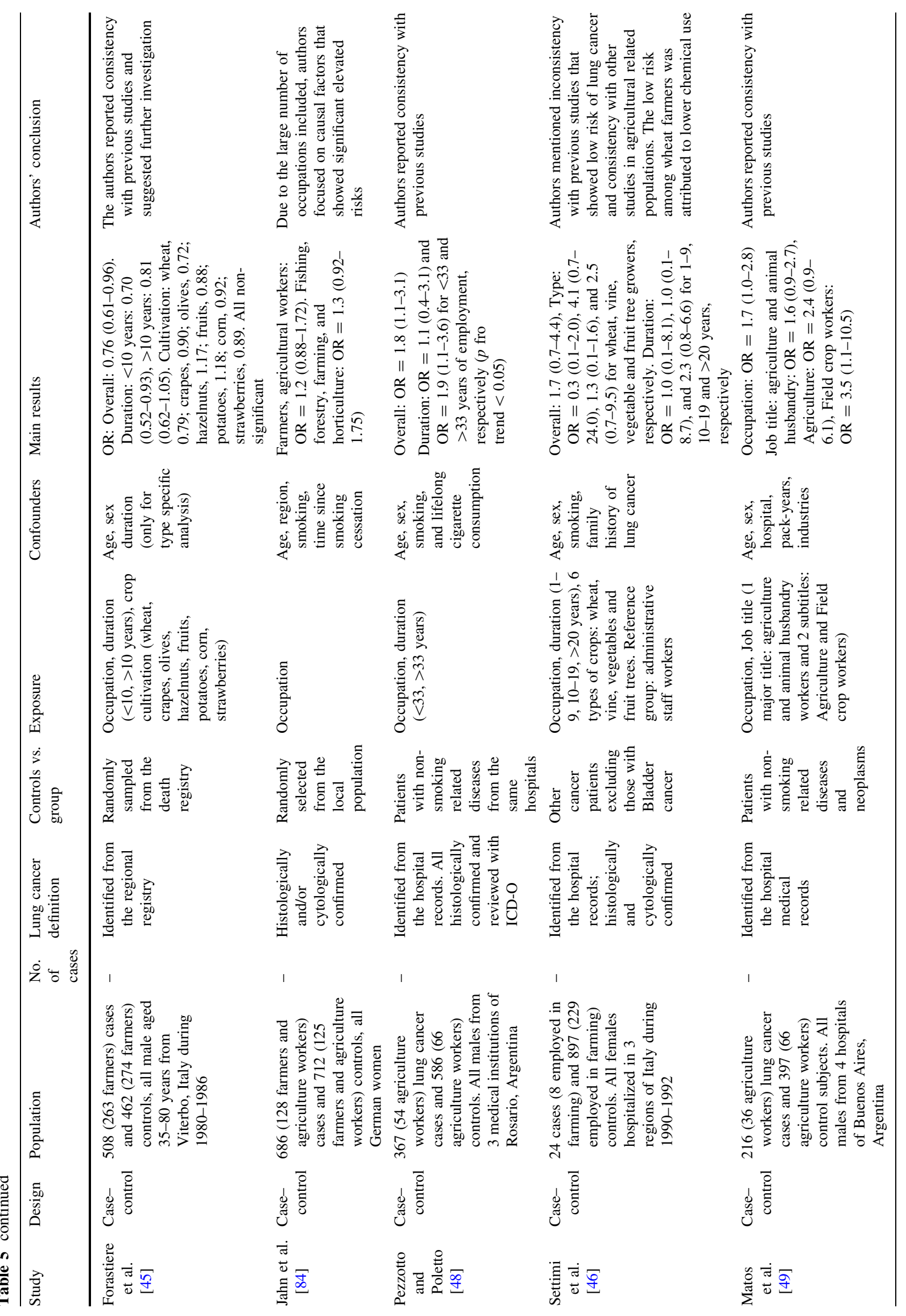




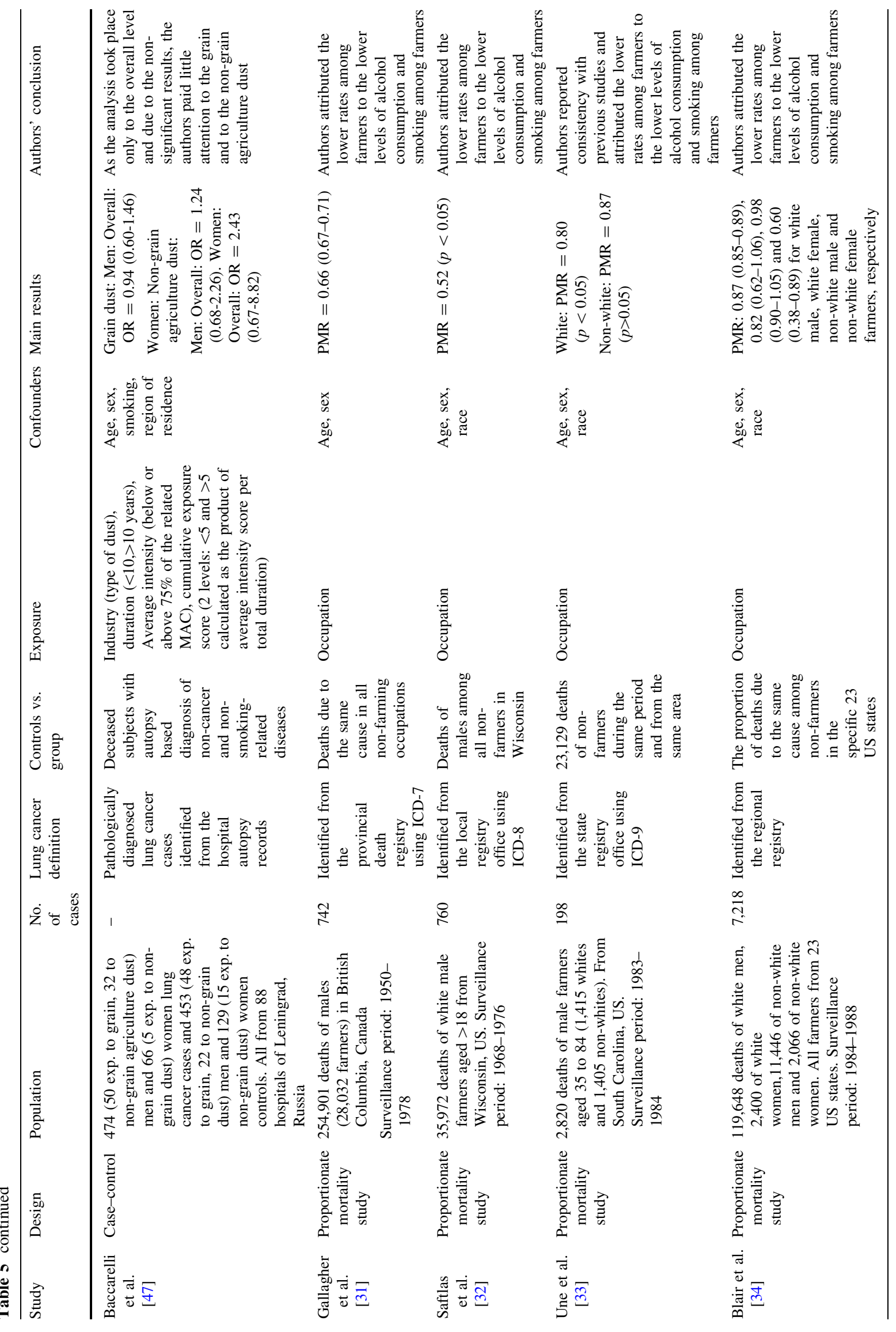




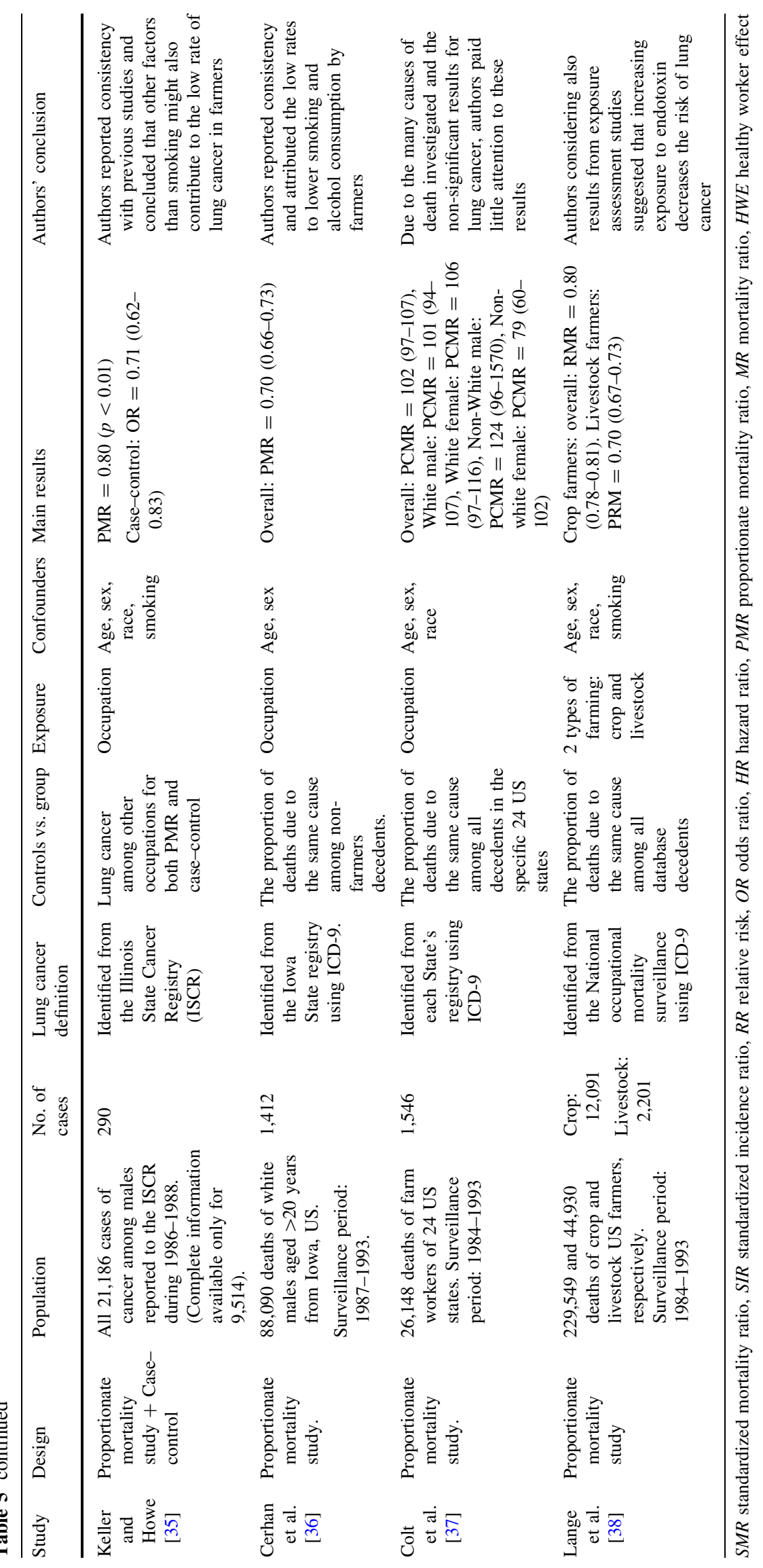




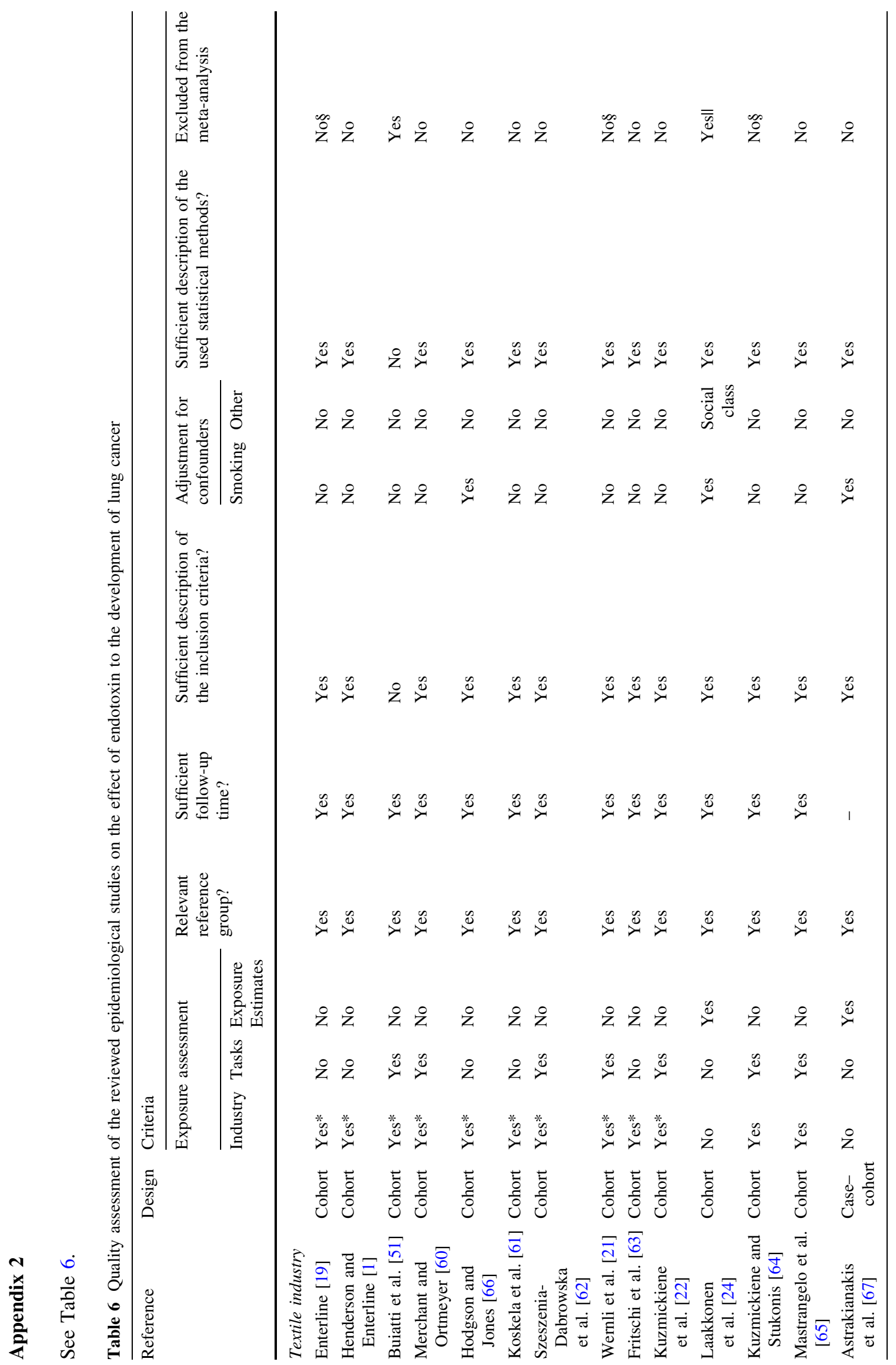




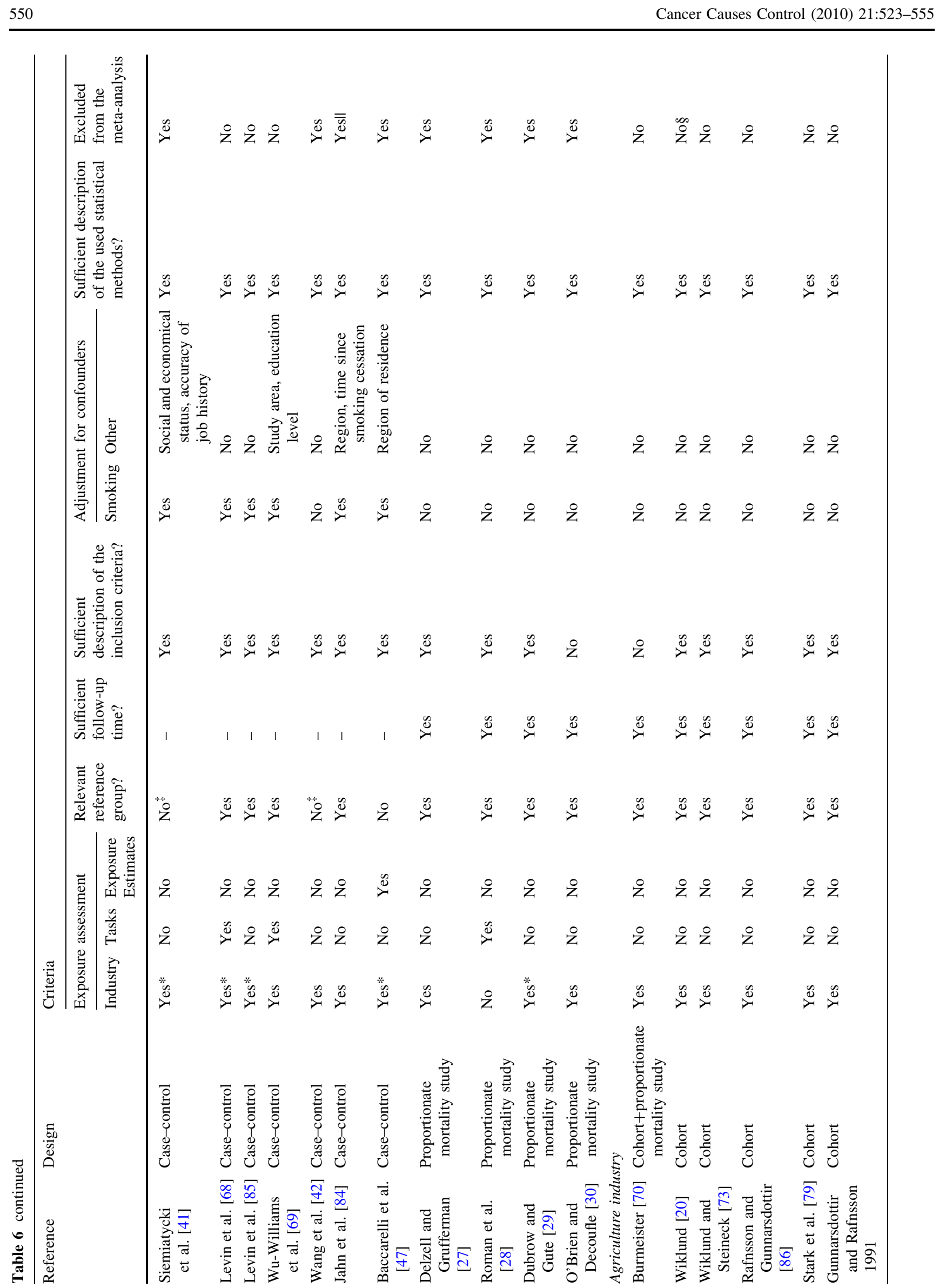

Springer 
Cancer Causes Control (2010) 21:523-555

551

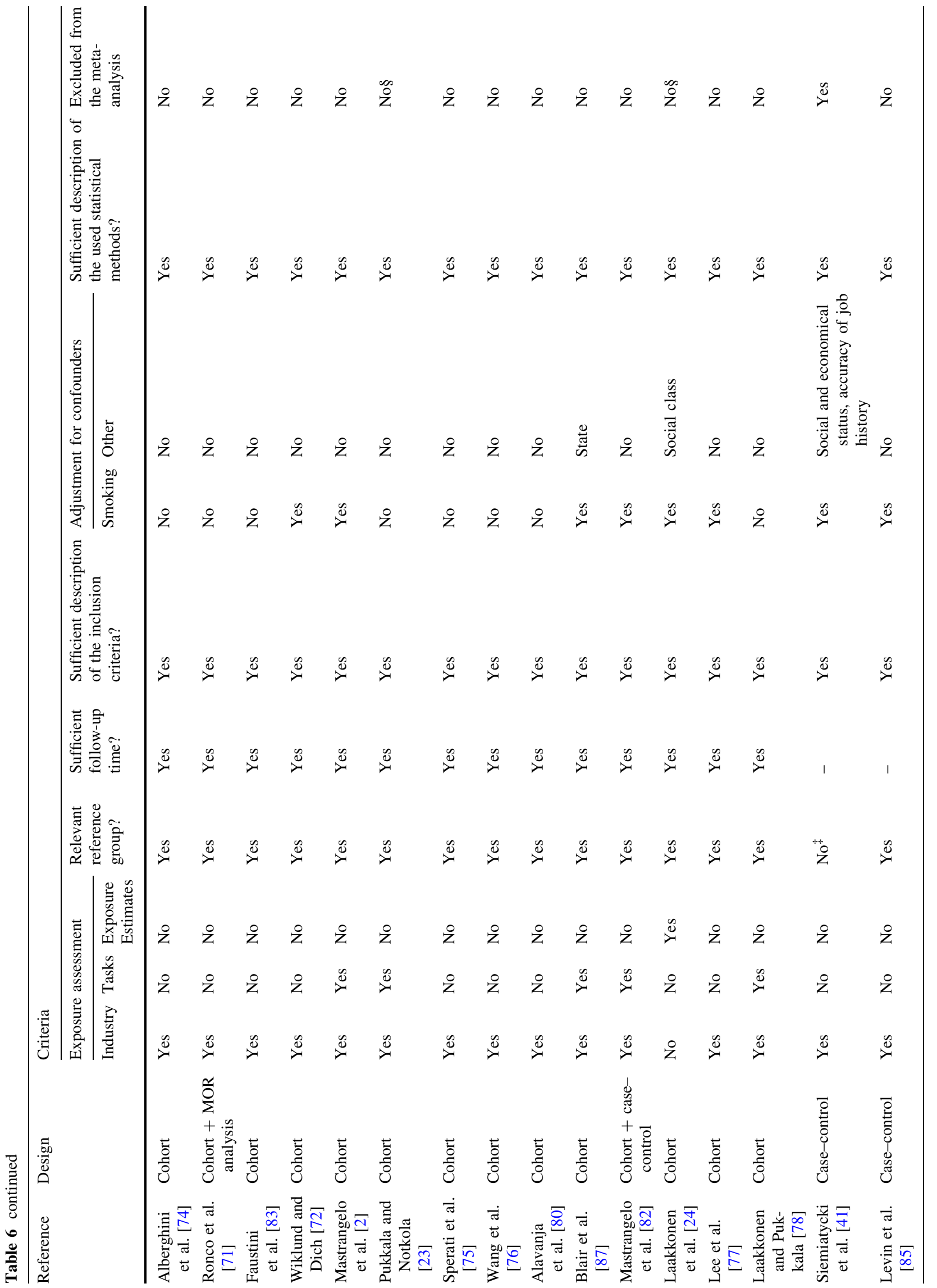

Springer 


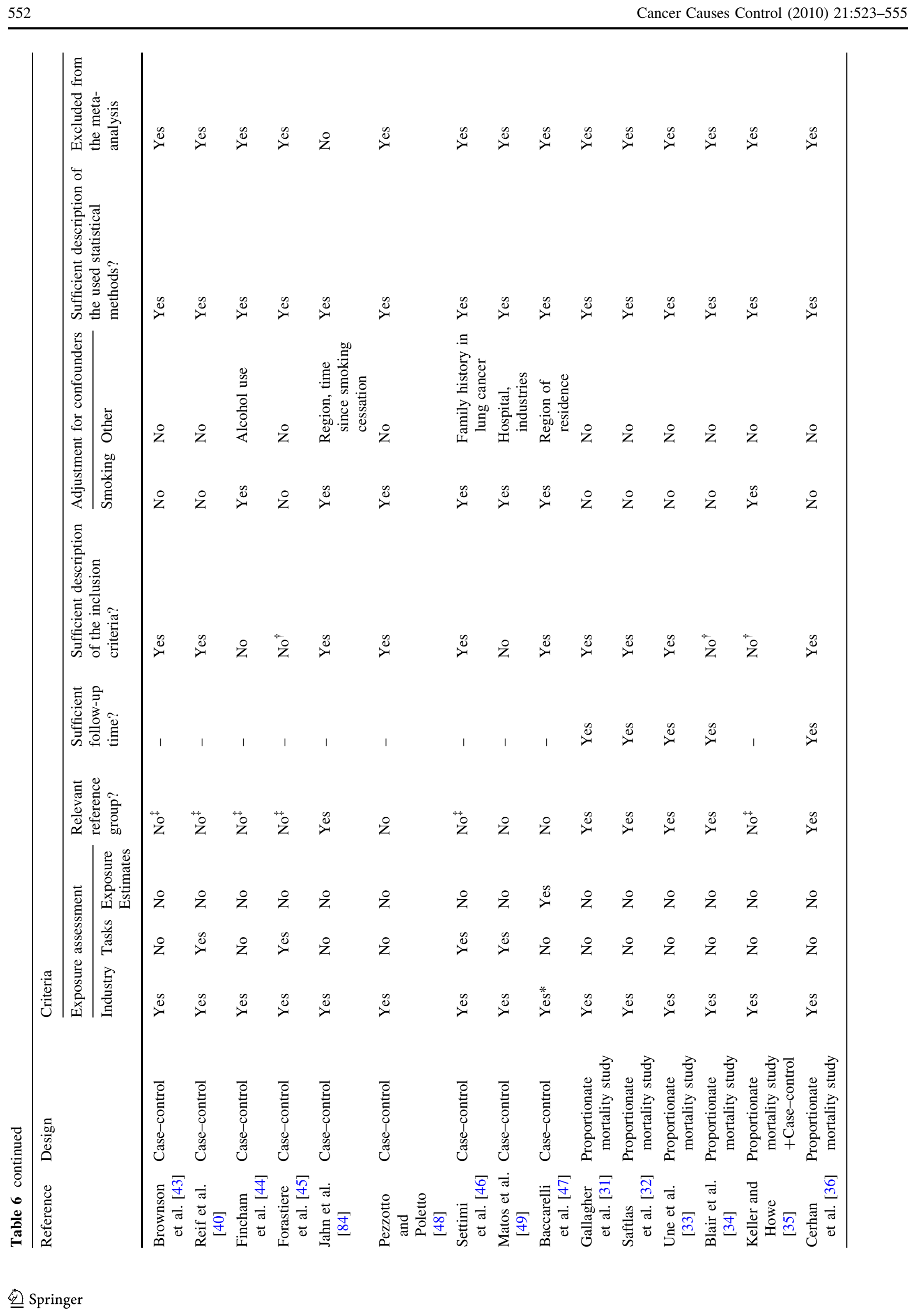




\section{References}

1. Henderson V, Enterline PE (1973) An unusual mortality experience in cotton textile workers. J Occup Med 15:717-719

2. Mastrangelo G, Marzia V, Marcer G (1996) Reduced lung cancer mortality in dairy farmers: is endotoxin exposure the key factor? Am J Ind Med 30:601-609

3. Mastrangelo G, Fedeli U, Fadda E, Milan G, Lange JH (2002) Epidemiologic evidence of cancer risk in textile industry workers: a review and update. Toxicol Ind Health 18:171-181

4. Lange JH (2000) Reduced cancer rates in agricultural workers: a benefit of environmental and occupational endotoxin exposure. Med Hypotheses 55:383-385

5. Enterline PE, Sykora JL, Keleti G, Lange JH (1985) Endotoxin, cotton dust, and cancer. Lancet 2:934-935

6. Liebers V, Brüning T, Raulf-Heimsoth M (2006) Occupational endotoxin-exposure and possible health effects on humans. Am J Ind Med 49:474-491

7. Reisser D, Pance A, Jeannin J (2002) Mechanisms of the antitumoral effect of lipid A. BioEssays 24:284-289

8. Otto F, Schmid P, Mackensen A et al (1996) Phase II trial of intravenous endotoxin in patients with colorectal and non-small cell lung cancer. Eur J Cancer 32A:1712-1718

9. Chicoine MR, Won EK, Zahner MC (2001) Intratumoral injection of lipopolysaccharide causes regression of subcutaneously implanted mouse glioblastoma multiforme. Neurosurgery 48:607-614

10. Pance A, Reisser D, Jeannin JF (2002) Antitumoral effects of lipid A: preclinical and clinical studies. J Investig Med 50:173178

11. Kobayashi K, Hernandez LD, Galán JE, Janeway CA Jr, Medzhitov R, Flavell RA (2002) IRAK-M is a negative regulator of Toll-like receptor signaling. Cell 110:191-202

12. Liebers V, Raulf-Heimsoth M, Brüning T (2008) Health effects due to endotoxin inhalation (review). Arch Toxicol 82:203-210

13. Su WL, Chen YH, Liou SH, Wu CP (2004) Meta-analysis of standard mortality ratio in cotton textile workers. Eur J Epidemiol 19:989-997

14. Blair A, Zahm SH (1991) Cancer among farmers. Occup Med 6:335-354

15. Acquavella J, Olsen G, Cole P et al (1998) Cancer among farmers: a meta-analysis. Ann Epidemiol 8:64-74

16. Davis DL, Blair A, Hoel DG (1993) Agricultural exposures and cancer trends in developed countries. Environ Health Perspect 100:39-44

17. Wouters IM, Spaan S, Douwes J, Doekes G, Heederik D (2006) Overview of personal occupational exposure levels to inhalable dust, endotoxin, $\beta(1 \rightarrow 3)$-glucan and fungal extracellular polysaccharides in the waste management chain. Ann Occup Hyg 50:39-53

18. Prazmo Z, Dutkiewicz J, Skórska C, Sitkowska J, Cholewa G (2003) Exposure to airborne Gram-negative bacteria, dust and endotoxin in paper factories. Ann Agric Environ Med 10:93100

19. Enterline PE (1965) Mortality among asbestos products workers in the United States. Ann N Y Acad Sci 132:156-165

20. Wiklund K (1983) Swedish agricultural workers. A group with a decreased risk of cancer. Cancer 51:566-568

21. Wernli KJ, Ray RM, Gao DL, Thomas DB, Checkoway H (2003) Cancer among women textile workers in Shanghai, China: overall incidence patterns, 1989-1998. Am J Ind Med 44:595-599

22. Kuzmickiene I, Didziapetris R, Stukonis M (2004) Cancer incidence in the workers cohort of textile manufacturing factory in Alytus, Lithuania. J Occup Environ Med 46:147-153 
23. Pukkala E, Notkola V (1997) Cancer incidence among Finnish farmers, 1979-93. Cancer Causes Control 8:25-33

24. Laakkonen A, Kyyronen P, Kauppinen T, Pukkala E (2006) Occupational exposure to eight organic dusts and respiratory cancer among Finns. Occup Environ Med 63:726

25. Wells GA, Shea B, O'Connell D, et al. (2006) The NewcastleOttawa scale (NOS) for assessing the quality of nonrandomised studies in meta-analyses. http://www.ohri.ca/programs/clinical_ epidemiology/oxford.htm. Accessed June 182008

26. Vlaanderen J, Vermeulen R, Heederik D, Kromhout H (2008) Guidelines to evaluate human observation studies for quantitative risk assessment. Environ Health Perspect 116:1700-1705

27. Delzell E, Grufferman S (1983) Cancer and other causes of death among female textile workers, 1976-78. J Natl Cancer Inst 71:735-740

28. Roman E, Beral V, Inskip H (1985) Occupational mortality among women in England and Wales. Br Med J (Clin Res Ed) 291:194-196

29. Dubrow R, Gute DM (1988) Cause-specific mortality among male textile workers in Rhode Island. Am J Ind Med 13:439454

30. O'Brien TR, Decouflé P (1988) Cancer mortality among northern Georgia carpet and textile workers. Am J Ind Med 14:15-24

31. Gallagher RP, Threlfall WJ, Jeffries E, Band PR, Spinelli J, Coldman AJ (1984) Cancer and aplastic anemia in British Columbia farmers. J Natl Cancer Inst 72:1311-1315

32. Saftlas AF, Blair A, Cantor KP, Hanrahan L, Anderson HA (1987) Cancer and other causes of death among Wisconsin farmers. Am J Ind Med 11:119-129

33. Une H, Schuman SH, Caldwell ST, Whitlock NH (1987) Agricultural life-style: a mortality study among male farmers in South Carolina, 1983-1984. South Med J 80:1137-1140

34. Blair A, Dosemeci M, Heineman EF (1993) Cancer and other causes of death among male and female farmers from twentythree states. Am J Ind Med 23:729-742

35. Keller JE, Howe HL (1994) Case-control studies of cancer in Illinois farmers using data from the Illinois State Cancer Registry and the U.S. census of agriculture. Eur J Cancer 30A:469473

36. Cerhan JR, Cantor KP, Williamson K, Lynch CF, Torner JC, Burmeister LF (1998) Cancer mortality among Iowa farmers: recent results, time trends, and lifestyle factors (United States). Cancer Causes Control 9:311-319

37. Colt JS, Stallones L, Cameron LL, Dosemeci M, Zahm SH (2001) Proportionate mortality among US migrant and seasonal farmworkers in twenty-four states. Am J Ind Med 40:604-611

38. Lange J, Mastrangelo G, Fedeli U, Fadda E, Rylander R, Lee E (2003) Endotoxin exposure and lung cancer mortality by type of farming: is there a hidden dose-response relationship? Ann Agric Environ Med 10:229-232

39. Decouflé P, Thomas TL, Pickle LW (1980) Comparison of the proportionate mortality ratio and standardized mortality ratio risk measures. Am J Epidemiol 111:263-269

40. Reif J, Pearce N, Fraser J (1989) Cancer risks in New Zealand farmers. Int J Epidemiol 18:768-774

41. Siemiatycki J, Richardson L, Gérin M et al (1986) Associations between several sites of cancer and nine organic dusts: results from an hypothesis-generating case-control study in Montreal, 1979-1983. Am J Epidemiol 123:235-249

42. Wang QS, Boffetta P, Parkin DM, Kogevinas M (1995) Occupational risk factors for lung cancer in Tianjin, China. Am J Ind Med 28:353-362

43. Brownson RC, Reif JS, Chang JC, Davis JR (1989) Cancer risks among Missouri farmers. Cancer 64:2381-2386
44. Fincham SM, Hanson J, Berkel J (1992) Patterns and risks of cancer in farmers in Alberta. Cancer 69:1276-1285

45. Forastiere F, Quercia A, Miceli M et al (1993) Cancer among farmers in central Italy. Scand J Work Environ Health 19:382389

46. Settimi L, Comba P, Carrieri P et al (1999) Cancer risk among female agricultural workers: a multi-center case-control study. Am J Ind Med 36:135-141

47. Baccarelli A, Khmelnitskii O, Tretiakova M et al (2006) Risk of lung cancer from exposure to dusts and fibers in Leningrad Province, Russia. Am J Ind Med 49:460-467

48. Pezzotto SM, Poletto L (1999) Occupation and histopathology of lung cancer: a case-control study in Rosario, Argentina. Am J Ind Med 36:437-443

49. Matos EL, Vilensky M, Mirabelli D, Boffetta P (2000) Occupational exposures and lung cancer in Buenos Aires, Argentina. J Occup Environ Med 42:653-659

50. Steenland K (1993) Studies in occupational epidemiology. Oxford University Press, Inc., New York

51. Buiatti E, Baccetti S, Cecchi F, Tomassini A, Dolara P (1979) Evidence of increased lung cancer rate among textile workers. Med Lav 70:21-23

52. Breslow NE, Day NE (1987) Statistical methods in cancer research. Volume II-The design and analysis of cohort studies. IARC Sci Publ 82:103-105

53. Higgins JPT, Thompson SG, Deeks JJ, Altman DG (2003) Measuring inconsistency in meta-analyses. BMJ 327:557-560

54. DerSimonian R, Laird N (1986) Meta-analysis in clinical trials. Control Clin Trials 7:177-188

55. Greenland S, O'Rourke K (2001) On the bias produced by quality scores in meta-analysis, and a hierarchical view of proposed solutions. Biostatistics 2:463

56. Sterne JAC, Egger M (2001) Funnel plots for detecting bias in meta-analysis: Guidelines on choice of axis. J Clin Epidemiol 54:1046-1055

57. Lau J, Ioannidis JPA, Terrin N, Schmid CH, Olkin I (2006) The case of the misleading funnel plot. BMJ 333:597-600

58. Begg CB, Mazumdar M (1994) Operating characteristics of a rank correlation test for publication bias. Biometrics 50:10881101

59. Egger M, Davey Smith G, Schneider M, Minder C (1997) Bias in meta-analysis detected by a simple, graphical test. BMJ 315:629

60. Merchant JA, Ortmeyer C (1981) Mortality of employees of two cotton mills in North Carolina. Chest 79:6S-11S

61. Koskela RS, Klockars M, Järvinen E (1990) Mortality and disability among cotton mill workers. Br J Ind Med 47:384-391

62. Szeszenia-Dabrowska N, Wilczynska U, Strzelecka A, Sobala W (1999) Mortality in the cotton industry workers: results of a cohort study. Int J Occup Med Environ Health 12:143-158

63. Fritschi L, Lakhani R, Nadon L (2004) Cancer incidence in textile manufacturing workers in Australia. J Occup Health 46:493-496

64. Kuzmickiene I, Stukonis M (2007) Lung cancer risk among textile workers in Lithuania. J Occup Med Toxicol 2: doi: 10.1186/1745-6673-2-14 (online 16 Nov 2007)

65. Mastrangelo G, Fadda E, Rylander R et al (2008) Lung and other cancer site mortality in a cohort of Italian cotton mill workers. Occup Environ Med 65:697-700

66. Hodgson JT, Jones RD (1990) Mortality of workers in the British cotton industry in 1968-1984. Scand J Work Environ Health 16:113-120

67. Astrakianakis G, Seixas NS, Ray R et al (2007) Lung cancer risk among female textile workers exposed to endotoxin. J Natl Cancer Inst 99:357-364 
68. Levin L, Gao Y, Blot W, Zheng W, Fraumeni JJ (1987) Decreased risk of lung cancer in the cotton textile industry of Shanghai. Cancer Res 47:5777-5781

69. Wu-Williams AH, Xu ZY, Blot WJ et al (1993) Occupation and lung cancer risk among women in northern China. Am J Ind Med 24:67-79

70. Burmeister L (1981) Cancer mortality in Iowa farmers, 197178. J Natl Cancer Inst 66:461-464

71. Ronco G, Costa G, Lynge E (1992) Cancer risk among Danish and Italian farmers. Br J Ind Med 49:220-225

72. Wiklund K, Dich J (1994) Cancer risks among female farmers in Sweden. Cancer Causes Control 5:449-457

73. Wiklund K, Steineck G (1988) Cancer in the respiratory organs of Swedish farmers. Cancer 61:1055-1058

74. Alberghini V, Luberto F, Gobba F, Morelli C, Gori E, Tomesani N (1991) Mortality among male farmers licensed to use pesticides. Med Lav 82:18-24

75. Sperati A, Rapiti E, Settimi L, Quercia A, Terenzoni B, Forastiere F (1999) Mortality among male licensed pesticide users and their wives. Am J Ind Med 36:142-146

76. Wang Y, Lewis-Michl EL, Hwang SA, Fitzgerald EF, Stark AD (2002) Cancer incidence among a cohort of female farm residents in New York State. Arch Environ Health 57:561-567

77. Lee DJ, Fleming LE, LeBlanc WG et al (2006) Occupation and lung cancer mortality in a nationally representative US cohort: The National Health Interview Survey (NHIS). J Occup Environ Med 48:823-832

78. Laakkonen A, Pukkala E (2008) Cancer incidence among Finnish farmers, 1995-2005. Scand J Work Environ Health 34:73-79

79. Stark AD, Chang HG, Fitzgerald EF, Riccardi K, Stone RR (1990) A retrospective cohort study of cancer incidence among New York State Farm Bureau members. Arch Environ Health 45:155-162

80. Alavanja MC, Sandler DP, Lynch CF et al (2005) Cancer incidence in the agricultural health study. Scand J Work Environ Health 31(Suppl 1):39-45 discussion 5-7

81. Gunnarsdóttir H, Rafnsson V (1991) Cancer incidence among Icelandic farmers 1977-1987. Scand J Soc Med 19:170-173

82. Mastrangelo G, Grange JM, Fadda E, Fedeli U, Buja A, Lange $\mathrm{JH}$ (2005) Lung cancer risk: effect of dairy farming and the consequence of removing that occupational exposure. Am J Epidemiol 161:1037-1046

83. Faustini A, Forastiere F, Di Betta L, Magliola EM, Perucci CA (1993) Cohort study of mortality among farmers and agricultural workers. Med Lav 84:31-41

84. Jahn I, Ahrens W, Brüske-Hohlfeld I et al (1999) Occupational risk factors for lung cancer in women: results of a case-control study in Germany. Am J Ind Med 36:90-100

85. Levin LI, Zheng W, Blot WJ, Gao YT, Fraumeni JF Jr (1988) Occupation and lung cancer in Shanghai: a case-control study. Br J Ind Med 45:450-458

86. Rafnsson V, Gunnarsdottir H (1989) Mortality among farmers in Iceland. Int J Epidemiol 18:146-151

87. Blair A, Sandler DP, Tarone R et al (2005) Mortality among participants in the Agricultural Health Study. Ann Epidemiol $15: 279-285$

88. Astrakianakis G, Seixas NS, Camp JE et al (2006) Modeling, estimation and validation of cotton dust and endotoxin exposures in Chinese textile operations. Ann Occup Hyg 50:573-582

89. Spaan S, Schinkel J, Wouters IM et al (2008) Variability in endotoxin exposure levels and consequences for exposure assessment. Ann Occup Hyg 52:303-316
90. Simpson JCG, Niven RML, Pickering CAC, Oldham LA, Fletcher AM, Francis HC (1999) Comparative personal exposures to organic dusts and endotoxin. Ann Occup Hyg 43:107115

91. Lane SR, Nicholls PJ, Sewell RDE (2004) The measurement and health impact of endotoxin contamination in organic dusts from multiple sources: focus on the cotton industry. Inhal Toxicol 16:217-229

92. Olenchock SA, Christiani DC, Mull JC, Ye TT, Lu PL (1983) Endotoxins in baled cottons and airborne dusts in textile mills in the People's Republic of China. Appl Environ Microbiol 46:817-820

93. Mehta AJ, Wang XR, Eisen EA et al (2008) Work area measurements as predictors of personal exposure to endotoxin and cotton dust in the cotton textile industry. Ann Occup Hyg 52:4554

94. Marchand G, Lalonde M, Beaudet Y, Boivin G, Villeneuve S, Pépin C (2007) Documentation of the endotoxins present in the ambient air of cotton fiber textile mills in Québec. J Environ Monit 9:869-876

95. Oldenburg M, Latza U, Baur X (2007) Exposure-response relationship between endotoxin exposure and lung function impairment in cotton textile workers. Int Arch Occup Environ Health 80:388-395

96. Su HJJ, Chen HL, Huang CF, Lin CY, Li FC, Milton DK (2002) Airborne fungi and endotoxin concentrations in different areas within textile plants in Taiwan: a 3-year study. Environ Res 89:58-65

97. Bakirci N, Kalaca S, Francis H et al (2007) Natural history and risk factors of early respiratory responses to exposure to cotton dust in newly exposed workers. J Occup Environ Med 49:853861

98. Hours M, Févotte J, Lafont S, Bergeret A (2007) Cancer mortality in a synthetic spinning plant in Besançon, France. Occup Environ Med 64:575-581

99. Kateman E, Heederik D, Pal TM, Smeets M, Smid T, Spitteler M (1990) Relationship of airborne microorganisms with the lung function and leucocyte levels of workers with a history of humidifier fever. Scand J Work Environ Health 16:428-433

100. Blair A, Stewart P, Lubin JH, Forastiere F (2007) Methodological issues regarding confounding and exposure misclassification in epidemiological studies of occupational exposures. Am J Ind Med 50:199-207

101. Myers J, Thompson M (1998) Meta-analysis and occupational epidemiology. Occup Med 48:99-101

102. Biggerstaff BJ, Tweedie RL (1997) Incorporating variability in estimates of heterogeneity in the random effects model in metaanalysis. Stat Med 16:753-768

103. Berman NG, Parker RA (2002) Meta-analysis: neither quick nor easy. BMC Med Res Methodol 2:10

104. Schilling RS, Hughes JP, Dingwall-Fordyce I, Gilson JC (1955) An epidemiological study of byssinosis among Lancashire cotton workers. Br J Ind Med 12:217-227

105. Christiani DC, Wegman DH, Eisen EA, Ye TT, Lu PL, Olenchock SA (1993) Cotton dust and gram-negative bacterial endotoxin correlations in two cotton textile mills. Am J Ind Med 23:333-342

106. Wang XR, Zhang HX, Sun BX et al (2005) A 20-year follow-up study on chronic respiratory effects of exposure to cotton dust. Eur Respir J 26:881-886

107. Rylander R (2007) Endotoxin in the air: good or bad for you? Clin Pulm Med 14:140-147 